\title{
Identifying key processes and sectors in the interaction between climate and socio- economic systems: a review toward integrating Earth-human systems
}

\author{
Kaoru Tachiiri ${ }^{*}$, Xuanming Su${ }^{1}$ and Ken'ichi Matsumoto ${ }^{1,2}$
}

\begin{abstract}
For the purpose of identifying the key processes and sectors involved in the interaction between Earth and socioeconomic systems, we review existing studies on those processes/sectors through which the climate impacts socioeconomic systems, which then in turn affect the climate. For each process/sector, we review the direct physical and ecological impacts and, if available, the impact on the economy and greenhouse gas (GHG) emissions. Based on this review, land sector is identified as the process with the most significant impact on GHG emissions, while labor productivity has the largest impact on the gross domestic product (GDP). On the other hand, the energy sector, due to the increase in the demand for cooling, will have increased GHG emissions. Water resources, sea level rise, natural disasters, ecosystem services, and diseases also show the potential to have a significant influence on GHG emissions and GDP, although for most of these, a large effect was reported only by a limited number of studies. As a result, more studies are required to verify their influence in terms of feedbacks to the climate. In addition, although the economic damage arising from migration and conflict is uncertain, they should be treated as potentially damaging processes.
\end{abstract}

Keywords: Earth system model, Integrated assessment model, Socio-economic system, Climate system, Human system

\section{Introduction}

Earth system models (ESMs) are global climate models (GCMs) that are coupled with biogeochemical components, such as the carbon cycle (Hajima et al. 2012; Kawamiya et al. 2020), and can be employed to simulate climate change for specific greenhouse gas (GHG) emission pathways. ESMs are characterized by transient climate sensitivity to airborne carbon, carbon sensitivity to airborne carbon, and carbon sensitivity to climate change (Friedlingstein et al. 2006), which, in combination, reflect the transient climate

\footnotetext{
* Correspondence: tachiiri@jamstec.go.jp

${ }^{1}$ Research Institute for Global Change, Japan Agency for Marine-Earth Science and Technology, 3173-25 Showa-machi, Kanazawa-ku, Yokohama 236-0001, Japan

Full list of author information is available at the end of the article
}

response to cumulative carbon emissions (TCRE; Gregory et al. 2009). The TCRE is a crucial parameter for carbon budget estimates that are designed to meet specific temperature targets, such as $1.5{ }^{\circ} \mathrm{C}$ or $2{ }^{\circ} \mathrm{C}$ set by the United Nations Paris Agreement (Rogelj et al. 2019). When ESMs are run for future climate projections, GHG-emission and land-use scenarios are quantified using the outputs of socio-economic models or integrated assessment models (IAMs; e.g., O'Neill et al. 2016). However, for more complete modeling, this approach may need to be modified to consider the interaction between Earth and human (particularly socio-economic) systems.

Climate change affects a wide variety of human systems. For example, Burke et al. (2015), Carleton and 
Hsiang (2016), and Hsiang et al. (2017) have shown that climate change impacts many socio-economic processes, such as human mortality rates, agricultural production, total factor productivity (TFP), migration, and conflict. Moreover, Diffenbaugh and Burke (2019) concluded that global warming has increased global economic inequality, and Moore and Diaz (2015) pointed out that warminginduced slowing of GDP growth is more significant in low-income countries. However, Beckage et al. (2018) raised the possibility that human behavior could have a significant impact on climate change projections. In this vein, Woodard et al. (2019) reported that economic carbon cycle feedbacks could be of a size comparable with and in the opposite direction of natural climate-carbon cycle feedbacks; thus, they may consequently offset each other. In particular, they decomposed $\mathrm{CO}_{2}$ emissions by population, gross domestic product (GDP) per capita, energy intensity (energy use per unit GDP), and carbon intensity $\left(\mathrm{CO}_{2}\right.$ emissions per unit of energy) based on the Kaya identity (Kaya and Yokobori 1997) and found that GDP per capita was the strongest factor of carbon emissions. GDP per capita is one of the more difficult-topredict quantities, and it has been claimed that a climatechange-produced gain in GDP per capita would reverse the sign of Woodard et al.'s (2019) main conclusion (Caldeira and Brown 2019).

To consider the interaction between Earth and human systems, one solution is to couple individual models of these systems. One such example is the simple coupled climate-economy system model proposed by KellieSmith and Cox (2011), which suggested that historically observed economic growth rates and decarbonization can lead the climate-economy system to experience damaging oscillations. When coupling more complicated models (e.g., an ESM and an IAM), van Vuuren et al. (2012) concluded that the most appropriate coupling approach depends on the situation under analysis and full coupling may not always be the most desirable approach. Indeed, coupling ESMs and IAMs is not an easy task because it requires matching spatial and temporal resolution (Chou et al. 2018), and differences between IAMs' focus on land use and ESMs' focus on land cover should be carefully accounted for (Bond-Lamberty et al. 2014; Robinson et al. 2018). Improving ESMs in terms of their simulations of agriculture and other types of land management is also important (McDermid et al. 2017; Pongratz et al. 2018).

Collins et al. (2015) developed an integrated Earth system and socio-economic model. Previously, Di Vittorio et al. (2014) suggested that using this type of model would moderate the gap between land use in IAMs and land cover in ESMs. Using the same model as Collins et al. (2015), Jones et al. (2018) showed that the inclusion of human-driven responses in an ESM altered both terrestrial concentration-carbon and climate-carbon feedbacks to increased carbon storage. Other similar models have also been proposed (Sokolov et al. 2005; Yang et al. 2015, 2016; Monier et al. 2018), including a model using an ESM of intermediate complexity (EMIC) instead of a state-of-the-art ESM (Mercure et al. 2018). However, Calvin and Bond-Lamberty (2018) concluded that more research and models were needed to robustly quantify the sign and magnitude of human-Earth system feedbacks.

This study aims to identify the key processes involved in the feedbacks from socio-economic systems to the climate. Given that the most important feedbacks from socio-economic systems to the climate occur via changes in GHG emissions, which in many cases occur via a change in economic growth, we evaluate the impact of these feedbacks in terms of the impact on the economy as a whole. It should be noted that there are other feedback processes linking socio-economic systems to the climate, which are discussed later.

In Section 2, we review previous studies on individual processes and sectors through which the climate affects human or socio-economic systems, particularly in terms of physical and ecological effects. These processes were selected from previous lists of processes/sectors used for impact assessment (e.g., IPCC 2014; Yokohata et al. 2019) based on the impact on the economy as a whole. This section focuses on presenting the results of relatively recent studies, particularly those that have followed the Fifth Assessment Report of the Intergovernmental Panel on Climate Change (IPCC), although it also refers to some important older studies. Section 3 discusses these findings, and Section 4 provides a conclusion.

\section{Feedback processes from climate to socio- economic systems}

In this section, after the impact on the whole economy, we discuss the impacts of climate change on eight key processes: land productivity (i.e., cropland and pasture), water resources, sea level rise (SLR) and inundation, natural disasters, other ecosystem services, human health (i.e., labor productivity and disease/health), industry and related economic activities (i.e., energy, infrastructure, tourism and transportation, insurance, and finance), and migration and civil/international conflict. Each subsection describes the physical and/or ecological effects of climate change on the process and the economic and GHG emission effects if available. In the end, we refer to additional topical issues and adaptation if available. Many studies referred to here use Representative Concentration Pathways (RCPs), but some studies use the Special Report on Emissions Scenarios (SRES) scenarios; see Supplementary Information (SI) for their comparison. In 
Table 1 Impact of climate change on GDP

\begin{tabular}{|c|c|c|c|c|}
\hline Study & $\begin{array}{l}\text { GDP } \\
\text { impact }\end{array}$ & $\begin{array}{l}\text { Climate } \\
\text { change } \\
\text { scenario }\end{array}$ & Model & Note \\
\hline Stern (2007) & $5-20 \%$ & $\mathrm{BAU}$ & Formal economic models & $\begin{array}{l}\text { The costs of mitigation can be limited to around } 1 \% \text { of global } \\
\text { GDP each year. There has been criticism on } \\
\text { the method of estimating damage and selection of parameter } \\
\text { values, including the utility discount rate (see, for example, Cole 2008) }\end{array}$ \\
\hline $\begin{array}{l}\text { Burke et al. } \\
\text { (2015) }\end{array}$ & $23 \%$ & $\begin{array}{l}\text { RCP8.5 } \\
(2100)\end{array}$ & - & $\operatorname{SSP}^{*} 5$ \\
\hline $\begin{array}{l}\text { Takakura et al. } \\
\text { (2019) }\end{array}$ & $\begin{array}{l}6.6 \%(3.9- \\
8.6 \%)\end{array}$ & $\begin{array}{l}\text { RCP8.5 } \\
(2100)\end{array}$ & Five ESMs & SSP3, strict mitigation could limit the impact to less than $1 \%$ \\
\hline Nordhaus (1994) & $0.60 \%$ & $\begin{array}{l}2^{\circ} \mathrm{C} \\
\text { increase }\end{array}$ & DICE & $\begin{array}{l}\text { The reference reports a damage function with which we } \\
\text { calculated the GDP impacts of } 2^{\circ} \mathrm{C} \text { warming. }\end{array}$ \\
\hline $\begin{array}{l}\text { Nordhaus and } \\
\text { Sztorc (2013), } \\
\text { Nordhaus (2014) }\end{array}$ & $1.10 \%$ & $\begin{array}{l}2^{\circ} \mathrm{C} \\
\text { increase }\end{array}$ & DICE & $\begin{array}{l}\text { The reference reports a damage function with which we } \\
\text { calculated the GDP impacts of } 2{ }^{\circ} \mathrm{C} \text { warming. }\end{array}$ \\
\hline Tol (2018) & $\begin{array}{l}0.1-3.0 \% \\
0.9-5.1 \% \\
6.1-6.7 \%\end{array}$ & $\begin{array}{l}2.5^{\circ} \mathrm{C}, 2.9- \\
3.2^{\circ} \mathrm{C}, 5.4- \\
6.0^{\circ} \mathrm{C}\end{array}$ & $\begin{array}{l}\text { Summarizing } 27 \text { studies on the } \\
\text { impact of the climate on the } \\
\text { economy }^{\mathrm{a}}\end{array}$ & - \\
\hline
\end{tabular}

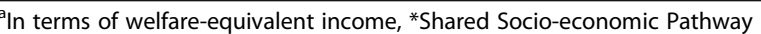

SI, the basic information of the studies cited are also presented as tables.

\subsection{Whole economy}

Stern (2007) estimated that for the business-as-usual (BAU) case, the overall costs and risks of climate change will be equivalent to losing $5-20 \%$ of GDP, while the costs of mitigation can be limited to around $1 \%$ of global GDP each year. In response to this, there has been criticism on the method of estimating damage and selection of parameter values, including the utility discount rate (see, for example, Cole 2008). We should also note that the impact on the economy strongly depends on the scenario and the level of warming. The GDP impacts reported in existing studies are summarized in Table 1 . In addition, Tol (2018) showed that warming of up to $1{ }^{\circ} \mathrm{C}$ had a positive effect on the economy, which is not dramatically different from Ueckerdt et al. (2019), who concluded that $1.9-2.0{ }^{\circ} \mathrm{C}$ was the economically optimal warming point when considering mitigation and adaptation costs. That is, slight warming could have a positive impact on the economy.

Meanwhile, Roson and van der Mensbrugghe (2012) concluded that changes in GHG emissions were nonnegligible; for example, they found that climate change impacts would lead to a $4.7 \%$ reduction of $\mathrm{CO}_{2}$ emissions worldwide by 2100 in addition to declines in methane $(8.4 \%)$ and $\mathrm{N}_{2} \mathrm{O}(7.8 \%)$ emissions ${ }^{1}$.

\subsection{Land productivity}

By altering temperature, precipitation, and radiation patterns that influence plant productivity, climate change

\footnotetext{
${ }^{1}$ For the BAU scenario.
}

affects cropland and pasture yields, which are vital to meet the demand for food. Sometimes, the effect of increasing the $\mathrm{CO}_{2}$ concentration, including the so-called $\mathrm{CO}_{2}$ fertilization and change in stomatal conductance, is excluded from the impact of climate change, but we include that impact, as climate change is always associated with a $\mathrm{CO}_{2}$ concentration increase.

\subsubsection{Cropland}

For the past, Iizumi et al. (2018) concluded that climate change decreased the mean global yields of maize, wheat, and soybeans in $1981-2010$ by $4.1 \%, 1.8 \%$, and $4.5 \%$, respectively, relative to when the preindustrial climate is input. Regionally, Matsumoto and Takagi (2017) found that an inverted U-shaped curve describes the relationship between temperature and rice production and also reported that, when climate change is large, production decreases in many cities, while the impact is relatively low in high-latitude regions.

For the future change, a comparison of multiple global gridded crop models revealed strong negative effects of climate change on crop (wheat, rice, maize, soybean) yields, particularly with high levels of warming at low latitudes and for models that explicitly incorporated nitrogen effects (Rosenzweig et al. 2014). In another study, it was observed for the same four crops that maize and soybean crop yields peaked for relatively slight warming (of $2-3{ }^{\circ} \mathrm{C}$ ), while rice yield kept increasing for greater warming (Iizumi et al. 2017) ${ }^{2}$. Under the SRES A1B scenario in 2050, changes in yields of spring wheat,

${ }^{2}$ In their study, wheat crops were negatively affected in low-income (which are often located at low latitudes) but not high-income countries (which are often located at mid and high latitudes). 
soybean, and maize, relative to the case in the absence of climate change, are projected to be $+1 \%,-13 \%$, and $22 \%$, respectively (Arnell et al. 2016a). Global (tuber) potato yields are also projected to decline by $2-6 \%$ by 2055, with larger declines expected by 2085 (2-26\%) depending on the RCP scenarios (Raymundo et al. 2018). Consistently, 12-53\% (adaptation of sowing date and thermal time requirements to give highest yields) and $2-27 \%$ (a more conservative adaptation of sowing date and thermal time requirements) increases are reported for the European Union (EU) for three SRES scenarios (A1B/B1/B2), and technological progress could even raise these numbers by $17-51 \%$ (Zimmermann et al. 2017). Another study on the $\mathrm{EU}$ found that, with $\mathrm{CO}_{2}$ fertilization, crop yield does not decline (RCP8.5, 2030), with the exception of maize (Blanco et al. 2017).

In the full adaptation case ${ }^{3}$, it has been estimated that the change in gross agricultural product will be around $+0.06 \%$ in 2100 , and that it will remain positive until the 2190s (Tol 2002b). Tol (2002b) also reported that each region has its own optimal warming for the agricultural sector, ranging from $0.45{ }^{\circ} \mathrm{C}$ to $3.41{ }^{\circ} \mathrm{C}$ (depending on the region).

In terms of impacts on GDP, Fujimori et al. (2018) concluded that the negative impact of changes in crop yield on GDP would be $0.02-0.06 \%$ (globally, the first and third quartiles) in 2100 even for RCP8.5, and the socio-economic assumption (choice of Shared Socioeconomic Pathway [SSP]) had an impact one order larger. A change in crop productivity could affect cropland area and crop price (Thornton et al. 2017; Calvin et al. 2019).

For the impact on total GHG emissions (including pastoralism) by 2050, 0.8 and $0.5 \mathrm{PgCO}_{2}$ increases, relative to the no climate change case, are estimated for SRES A1 and B1 scenarios, respectively (Bajželj and Richards 2014), which is equivalent to 5 and $3 \%$ of total emissions for the two scenarios. The impact of warming on agriculture estimated by Takakura et al. (2019) is slightly positive for RCP2.6, 4.5 , and 6.0 but negative for RCP8.5, while Nordhaus and Boyer (1999) estimated the damage for $2.5{ }^{\circ} \mathrm{C}$ warming as $0.06 \%$ of GDP (output weighted).

For additional information, Reilly et al. (2007) argued that climate change and increases in $\mathrm{CO}_{2}$ levels will generally have a positive effect, but ozone damage could offset these benefits if it is not strongly controlled. Attention also needs to be paid to subsistence and smallholder farmers, predominantly those in developing

\footnotetext{
${ }^{3}$ It assumes substantial changes to agricultural systems with investment in regional/national agricultural infrastructure and policy changes, including large shifts in planting dates, an increase in fertilizer requirements, the installation of irrigation systems, and the development of new crop varieties (Rosenzweig and Parry 1994).
}

countries, which are vulnerable to climate change (Morton 2007).

Additionally, the adaptation cost needed to offset the negative effect of climate change is estimated to be around 7 billion US dollars (USD) per year, including mainly regional target changes (e.g., irrigation efficiency, rural roads, and agricultural research) (Nelson et al. 2009). Smit and Skinner (2002) classified the agricultural adaptation options into four categories: (1) technological developments, (2) government programs and insurance, (3) farm production practices, and (4) farm financial management. They include crop development, weather and climate information systems, and resource management innovations (1); agricultural subsidy and support programs, private insurance, and resource management programs (2); farm production, land use, land topography, irrigation, and timing of operations (3); and crop insurance, crop shares and futures, income stabilization programs, and household income (4).

\subsubsection{Pasture and livestock}

Climate change is a threat to livestock production due to its influence on feed crop and forage quality, water availability, animal and milk production, livestock diseases, animal reproduction, and biodiversity (RojasDowning et al. 2017). In addition, the variety of livestock systems in operation globally complicates the discussion surrounding the effects of climate change (Lopez-iGelats 2014; Rivera-Ferre et al. 2016). Inter-model uncertainty (e.g., what Chen et al. (2018) demonstrated regarding carbon sequestration from grazing activity) also remains a problem.

For RCP8.5 in 2050, herbaceous net primary production (NPP) would increase slightly by an average of 3 $\mathrm{gC} / \mathrm{m}^{2} /$ year, although overall NPP is expected to decrease (Boone et al. 2018). It was also pointed out that greater precipitation variability, which is a likely consequence of global warming, could have a negative impact on vegetation recovery (Martin et al. 2014). In particular, it was suggested that desertification could have a negative impact (Nardone et al. 2010). For economic impact, globally, under RCP8.5, it is projected that there will be a $7.5-9.6 \%{ }^{4}$ decline in grazing livestock as a proportion of total stocking in rangelands and an economic loss of 9.7-12.6 ${ }^{4}$ billion USD by 2050 (Boone et al. 2018).

In addition, many studies (e.g., Olwoch et al. 2008; Gray et al. 2009; Wilson and Mellor 2009) have reported a positive relationship between temperature and the expansion of the geographical range of arthropod vectors

\footnotetext{
${ }^{4}$ For 7 GCMs

${ }^{5}$ For example, the study by Bett et al. (2017) on tsetse flies, which transmit a range of trypanosome parasites in sub-Saharan Africa. The same study also found that extreme events such as drought promote livestock diseases.
} 
for livestock diseases, but other research has found the opposite ${ }^{5}$.

For adaptation, as the impact of climate change is known to be region-dependent, it is pointed out that locking pastoral societies into specified development pathways could be maladaptive (Herrero et al. 2016a). The following are mentioned as adaptation measures: modifying production and management systems (e.g., diversification of livestock animals, application of agroforestry), changing breeding strategies, and improving farmers' perceptions and adaptive capacity (Rojas-Downing et al. 2017). As mitigation measures, the same study mentioned performing carbon sequestration through decreasing deforestation rates and/or improving animal and herd efficiency, reducing enteric fermentation through practices such as improvement of animal nutrition and genetics, improving manure management and fertilizer management, and shifting human dietary trends.

\subsection{Water resources}

On average, precipitation is increased by global warming. However, the spatial heterogeneity of the rainfall change and increased demand for water (mainly due to increasing populations and economic growth) can cause water scarcity in some regions (this is already evident, and it will further increase in the future).

Two indicators are widely used for assessing water scarcity: water crowding index $(\mathrm{WCI})^{6}$ and water stress index (WSI) ${ }^{6}$.

For the past, using WSI, it is estimated that 800 million people or $27 \%$ of the global population were living under water-stressed conditions in 1960, and this number eventually increased to 2.6 billion or $43 \%$ by 2000 (Wada et al. 2011). This number was slightly lowered by Gosling and Arnell (2016) who, using 21 GCMs, estimated that between 1.6 (based on WCI) and 2.4 (WSI) billion people, respectively, were experiencing water scarcity in 2000. However, the main reason for that is considered the increase of human water demand rather than climate change.

For the future, the global population exposed to water shortages (i.e., the situation in which water stress is acknowledged to be a factor limiting development) is projected to further increase significantly. Gosling and

\footnotetext{
${ }^{5}$ For example, the study by Bett et al. (2017) on tsetse flies, which transmit a range of trypanosome parasites in sub-Saharan Africa. The same study also found that extreme events such as drought promote livestock diseases.

${ }^{6} \mathrm{WCI}$ is an index of the annual water resources per capita in a watershed, and a WCI threshold of $<1,000 \mathrm{~m}^{3} /$ capita/year is often used as an indicator of water scarcity. WSI is an index of the ratio of water withdrawals to resources, and a WSI of $>0.4$ is used to indicate water scarcity. In many cases, WSI > 0.4 results in larger (by $30-50 \%$ ) population exposure than a WCI threshold of $<1,000 \mathrm{~m}^{3} /$ capita/year.
}

Arnell (2016) reported 37\% and 53\% population exposure to water scarcity without climate change impact with WCI $<1,000 \mathrm{~m}^{3} /$ capita/year and WSI $>0.4$, respectively $^{7}$. In their multi-model study, Schewe et al. (2014), using WCI for RCP8.5, projected that, compared with a population-growth-only scenario, global warming of $2{ }^{\circ} \mathrm{C}$ above current temperatures would lead to a $15 \%$ increase in the global population facing a severe reduction in access to water resources. They also projected that the number of people experiencing absolute water scarcity (defined as $<500 \mathrm{~m}^{3}$ per capita annually) would increase by an additional $40 \%$. All of the baseline and different mitigation scenarios considered in the paper resulted in $51-57 \%^{8}$ global population exposure to water scarcity in 2050 (Hejazi et al. 2014 using WSI), while Hanasaki et al. (2013) using WSI suggested smaller percentages of $25-28 \%{ }^{9}$ for RCP2.6, 4.5 , and 8.5. Arnell and Lloyd-Hughes (2014) using WCI estimated that under RCP2.6, exposure to a higher frequency of flooding would be reduced by around $16 \%$ in 2050, and exposure to greater water scarcity would be reduced by $22-24 \%$ compared with RCP8.5. The number of people exposed to water resource stress for the SRES A2 scenario is projected to be $10-20 \%$ larger than that for the A1B and B2 scenarios (Arnell et al. 2016b).

At least on a regional scale, mitigation and adaptation policies could increase water scarcity. Hejazi et al. (2015) concluded that twenty-first-century United States (US) emissions mitigation could increase water stress (e.g., irrigation for biocrops), and Haddeland et al. (2014) indicated that the water scarcity due to irrigation was significant in parts of southern and eastern Asia in 19702000, and it is expected to become even larger in the future.

For economic impact, the water resource damage for 1 ${ }^{\circ} \mathrm{C}$ warming is estimated to be 84 billion USD (Tol 2002a). Under Tol's (2002b) scenario ${ }^{10}$, in 2100 , this will cause a damage corresponding to around $0.6 \%{ }^{11}$ of the world GDP. The adaptation measures fall into two areas, management (socio-economic context) and technical solutions, and they are then categorized as follows: wider scope of management, adequate governance and strong institutions, intensification of demand management and supply enhancement, system interconnection and optimal operation, revisiting water rights and water

\footnotetext{
${ }^{7}$ For the future population of the SRES A1B storyline represented by an IAM.

${ }^{8}$ It depends on the radiative forcing target and tax regime (see Table 4. of Hejazi et al. 2014).

${ }^{9}$ These values vary depending on the RCP scenario.

${ }^{10}$ In Tol (2002b), the scenario used for that study is not described. We assumed that the author used the FUND standard scenario, which is relatively similar to the SRES/B2 scenario (Warren et al. 2006).

${ }^{11}$ Central value
} 
allocation procedures, and early warning and risk management (of drought) (Garrote 2017). For the Maldives, the desalination of water has been mentioned as a "hard" ${ }^{2}$ adaptation measure (Sovacool 2012).

\subsection{SLR and inundation}

Global warming causes additional ocean heat uptake, which causes thermal expansion of the ocean water and the melting of ice and snow, leading to freshwater inflow from land to oceans, both of which contribute to SLR. SLR inundates coastal areas, negatively affecting the local people's lives and economic activities. Relative SLR has a range of potential impacts, including higher extreme sea levels (and associated flooding), coastal erosion, the salinization of surface water and groundwater, and the degradation of coastal habitats such as wetlands (Nicholls 2011).

The satellite observations in 1993-2009 showed that SLR was spatially varying. In the western tropical Pacific Ocean, Southern Ocean, and part of the North Atlantic Ocean, SLR (around $12 \mathrm{~mm} /$ year) has increased 3-4 times faster than the global mean $(3.2 \mathrm{~mm} /$ year) (Meyssignac et al. 2012). For RCP4.5 in 2081-2100 (relative to 1986-2005), SLR of $0.5-0.6^{13} \mathrm{~m}$ is projected in the northern tropical ocean and southern Pacific Ocean, and $0.4-0.6^{13} \mathrm{~m}$ is projected for other small island regions (Nurse et al. 2014). These figures indicate the severe future condition for the Pacific small island countries. Under the SRES A1B scenario in 2050, the loss of coastal wetland area and the additional number of people affected by coastal flooding compared with a non-climate change case ${ }^{14}$ are projected to be $15 \%$ and 1.3 million, respectively (Arnell et al. 2016a).

For economic impact, a study using a static computable general equilibrium (CGE) model found that SLR could have a significant impact on agriculture in 2050 when no protection is applied (Bosello et al. 2007). In that case, a slight GDP loss $(0.0-0.1 \%$ for eight regions) and small change in $\mathrm{CO}_{2}$ emissions (0.02 to $+0.04 \%$ for the same regions) was estimated, and for the total protection scenario, those numbers were -0.10 to $+0.02 \%$ (GDP loss) and -0.34 to + $0.07 \%\left(\mathrm{CO}_{2}\right.$ emissions). A $25-\mathrm{cm}$ SLR in 2050 results in $0-0.2 \%$ (among 16 regions) of GDP direct cost, $0.00-0.11 \%$ GDP loss, and -0.15 to $+0.03 \% \mathrm{CO}_{2}$

\footnotetext{
${ }^{12}$ Hard adaptation measures typically employ capital-intensive, large, complex, and inflexible technology and infrastructure, whereas soft adaptation measures prioritize natural capital, community control, simplicity, and appropriateness (Sovacool 2011). Sovacool (2012) reported one hard and one soft measure for water scarcity and other problems (e.g., SLR, tidal inundation; see also the end of Section 2.9.1).

${ }^{13}$ The range appears to be for different regions.

${ }^{14}$ For HadCM3 model (with $3.5 \mathrm{~K}$ equilibrium climate sensitivity; Hunter et al. 2019).
}

emission changes (Bigano et al. 2008); in particular, the impact of SLR on the tourism sector was considerable. Wetland loss for $1 \mathrm{~m}$ SLR was projected to be $170,000 \mathrm{~km}^{2}$, and the protection cost will be 1.06 trillion USD (Tol 2002a).

It was identified that SLR is a particular risk for rice production in Bangladesh, Japan, Taiwan, Egypt, Myanmar, and Vietnam. Using a global rice trade model with an SLR of 0-5 $\mathrm{m}$, it was found that global rice production would fall by $1.60 \%$ for the no SLR case and $1.81-2.73 \%$ for $1-5 \mathrm{~m}$ SLR and that global rice prices would rise by $7.14 \%$ and 8.12 $12.77 \%$, respectively (Chen et al. 2011).

The global total damage cost by SLR is estimated to reach 200/1000/2000 billion USD for $0.5 \mathrm{~m} / 1 \mathrm{~m} / 2 \mathrm{~m}$ SLR, respectively, and for a $0.5-\mathrm{m}$ rise, it is shown that protection (of developed coastal areas) and wetland damage are the two main factors (others considered are dryland damage and mitigation cost) (Anthoff et al. 2010). For a 1-m rise, the Federal States of Micronesia have > 5\% of GDP damage, but by protection, 500 billion USD can be saved in 2100 (Anthoff et al. 2010). The inundated area is estimated to be 370,000 (RCP2.6)-420,000 $\mathrm{km}^{2}$ (RCP8.5), and the affected population is expected to range from 55.3 million (RCP2.6, SSP1) to 106 million (RCP8.5, SSP3) for 2100 (Tamura et al. 2019). Nordhaus and Boyer (1999) estimated the damage for $2.5{ }^{\circ} \mathrm{C}$ warming as $0.32 \%$ (output weighted) or $0.12 \%$ (population weighted) of GDP, indicating that high-income regions have large damages.

For the US, it was found that incorporating sitespecific episodic storm surges doubled national damage estimates relative to SLR-only estimates (Neumann et al. 2014). At the city level, Hallegatte et al. (2011) estimated sector-by-sector losses due to an SLR of $2 \mathrm{~m}$ above the current sea level for Copenhagen, Denmark in the absence of any protective measures. Transport, postal services, telecommunications, public and personal services, and the housing sector were predicted to experience the greatest direct losses (> 800 million EUR), followed by manufacturing, electricity, gas and water supply, and finance and business activities (400-600 million EUR).

For adaptation, it is suggested that dikes of $1 \mathrm{~m}$ in height may reduce the total inundated area by approximately $40 \%$ below the no-adaptation baseline under the same RCP scenarios through 2020-2100 (Tamura et al. 2019). The adaptation cost is estimated to be 10 and 50 billion USD in 2050 for new dikes and updated dikes, and for 2100, the cost will be 100-200 (new dikes) and 30-50 billion USD (updated dikes). The benefit-cost ratio is $\leq 1$ for new dikes and $>1$ for upgraded dikes for both RCP2.6 and 8.5 (Tamura et al. 2019). 


\subsection{Natural disasters}

A warm atmosphere can hold more water (by about $7 \%$ per $1{ }^{\circ} \mathrm{C}$ ), which causes more rainfall. A change in the spatial pattern of rainfall distribution has been observed, with dry areas (generally throughout the subtropics) becoming drier and wet areas becoming wetter (Trenberth 2008), while developing countries and smaller economies are more vulnerable to natural disasters (Noy 2009). Although Bouwer (2011) concluded that anthropogenic climate change to date has not had a significant impact on losses from natural disasters, all projections indicated that there would be an increase in extreme weather losses due to climate change.

Until 2040, however, greater exposure to natural disasters due to population growth and the higher capital value at stake are likely to have an equal or larger effect on disaster losses than anthropogenic climate change (Bouwer 2013). In particular, for tropical cyclones, a review article concluded that a future projection indicates a $2-11 \%$ increase in intensity by 2100 , with a $6-34 \%$ decrease in frequency (with a $20 \%$ increase in the most intense cyclones) (Knutson et al. 2010). For RCP2.6 and 8.5, climate change by 2050 would increase exposure to river flood risk for $93-530$ and 100-580 million $^{15}$ people, respectively (Arnell and Lloyd-Hughes 2014). In an analysis under the SRES A1B scenario, Arnell and Gosling (2016) concluded that, in 2050, 31-450 million people and $59,000-430,000^{16} \mathrm{~km}^{2}$ of cropland would be exposed to the risk of river flooding with doubled frequency. Even without climate change, tropical cyclone damage will be doubled (56 billion USD/year, equivalent to $0.01 \%$ of GDP from the current 26 USD billion/year, equivalent to $0.04 \%$ of GDP) likely due to future increases in income, and climate change damage doubles that (53 billion/year). That damage was concentrated in North America, East Asia, and the Caribbean-Central America $(0.0-0.2 \%$ as GDP loss rate, Mendelsohn et al. 2012). Gariano and Guzzetti (2016) presented a map displaying projected future occurrences of four landslide types, suggesting that the frequency of debris flow and shallow landslides would increase in many parts of the world. Cloutier et al. (2016) reported that in Canada, warming would impact permafrost, glaciers, and ice caps, leading to landslides. In a CGE-based analysis, the impact of fluvial floods on GDP was negligible (Takakura et al. 2019).

For adaptation, many studies (e.g., Mercer 2010) have emphasized the importance of integrating disaster risk reduction and climate change adaptation, and Birkmann and von Teichman (2010) concluded that the main barriers to this can be grouped into three categories: (1) spatial and temporal scales, (2) norm systems (e.g.,

\footnotetext{
${ }^{15}$ For 19 GCMs.

${ }^{16}$ For 21 GCMs.
}

legislative, cultural, or behavioral), and (3) knowledge types and sources. For drought in the Sahel, considering the uncertainty in future climate change, Mortimore (2010) emphasized that the adaptation policies should aim to build on the platform of past achievements and existing local knowledge to enable flexibility and diversity and the protection of assets of small-scale farmers and herders.

\subsection{Ecosystem services}

Climate change can alter the living environments of many creatures, influencing their existence, which in turn impacts the profit they give us. The functions of ecosystem services can be categorized into four types: supporting (e.g., primary production, nutrient cycling), provisioning (e.g., food, water), regulating (e.g., climate, water, disease), and cultural (e.g., recreation, education) (Millennium Ecosystem Assessment 2005). The Economics of Ecosystems and Biodiversity (TEEB) (2009) mentioned three climate-related issues: coral reef, forest carbon, and investment for climate adaptation. Moreover, Staudinger et al. (2012) for the US identified climate change as having an effect on marine fishery yields, nature-dependent tourism, hazard reduction, and carbon storage/sequestration. Similarly, Grimm et al. (2013) reported that the loss of sea ice, rapid warming, and higher organic inputs affect marine and lake productivity, while the combined influence of wildfires and insect outbreaks reduces forest productivity, mostly in arid and semi-arid western regions of the US. They also reported that ecosystem feedbacks, especially those associated with the release of $\mathrm{CO}_{2}$ and $\mathrm{CH}_{4}$ from wetlands and the thawing of permafrost soils, accelerate the rate of climate change.

Shaw et al. (2011) examined how two important ecosystem services in California, carbon sequestration and rain-fed forage production for livestock, were affected by climate change in terms of their distribution and production levels. Based on various climate change scenarios, they predicted that the availability and value of these ecosystem services would decline under most GHG trajectories.

Traditional healthcare systems, which rely on medicinal plants, are also likely to be affected by climate change. In the Himalayan region, persistent climatic variability would alter the habitats of medicinal plants (Maikhuri et al. 2017) $^{17}$. The total ecosystem value at 2005 is evaluated as 1.3 trillion international dollars, and $20-50 \%$ of that will experience the climate category transition by 2100 (Watson et al. 2020).

\footnotetext{
${ }^{17}$ Changes in the phenophases of medicinal plants would require an adjustment to the collection period for these plants, which would go against tradition, while other species would need to be used as substitutes in traditional healthcare systems.
} 
For the future, as an example of hazard reduction, it was suggested that GHG mitigation (to $3.7 \mathrm{~W} / \mathrm{m}^{2}$ target) had potential ecosystem service benefits, on determining the wildfire pattern, of 3.5 billion USD on average in 2005 dollars $^{18}$ for $2013-2115$ (Lee et al. 2015).

It was concluded that in 2070-2099 (with RCP8.5), for southern California, water runoff $(+127 \% \text { to }-60 \%)^{19}$ and carbon storage $(+52 \% \text { to }-31 \%)^{19}$ were likely to be most significantly affected. Moreover, one-third of highbiodiversity areas were threatened by potential water deficits, and the annual costs of sediment removal were estimated to be around 172 million USD and carbon storage was estimated to be worth 7.5 billion USD (Underwood et al. 2019). For a Mediterranean river basin, it was reported that the availability of drinking water was expected to decrease by $3-49 \%{ }^{20}$, while total hydropower production would decrease by $5-43 \%{ }^{20}$. In addition, erosion control was estimated to be $23 \%$ lower, indicating that the costs required for dredging reservoirs and treating drinking water would also increase (Bangash et al. 2013). Impacts of $1{ }^{\circ} \mathrm{C}$ warming and $\mathrm{CO}_{2}$ fertilization are projected to be 439 million and - 50 million USD for forestry and natural ecosystems, respectively (Tol 2002a). The cost of loss of species, ecosystems, landscapes, and so on is estimated to be around $0.04 \%$ of GDP in 2100 (Tol 2002b).

For the impact of adaptation on ecosystem services, not only the complex interactions between different ecosystem processes but also tradeoffs between ecosystem services, including the positive effects of increasing temperatures on food and timber production and the longer growing season and the negative effects of more frequent fungal disease and insect outbreaks, were found in cool Finnish regions (Forsius et al. 2013). Recently, ecosystem-based adaptation (EbA), defined as "the use of biodiversity and ecosystem services to help people adapt to the adverse effects of climate change" (SCBD 2009), is advocated and attempted here and there (e.g., Huq et al. 2017; Newsham et al. 2018).

\subsection{Human health}

Human health can also be affected by climate change. Here, we focus on the impact on labor productivity due to heat stress, the spread of disease, and other healthrelated issues.

\subsubsection{Decrease in labor productivity}

Hot working environments affect workers (Tawatsupa et al. 2013; Xiang et al. 2014); heat stress has already

\footnotetext{
${ }^{18}$ Assuming a 3\% discount rate.

${ }^{19}$ Depending on GCM.

${ }^{20}$ Depending on scenario (SRES/A2 or B1) and period (2001-30, 2031-2070, 2071-2100).
}

reduced labor capacity to an estimated $90 \%$ during peak months over the past few decades (Dunne et al. 2013), with the impact greater for those working outdoors (e.g., agricultural workers) than those working indoors (e.g., office workers; Kjellstrom et al. 2009b). A case study on the steel industry in southern India found that the productivity loss of workers exposed to wet-bulb globe temperatures (WBGTs) above the threshold was significantly higher among workers with direct rather than indirect heat exposure (Krishnamurthy et al. 2017). In construction projects in China, it was found that direct working time declined by $0.57 \%$ and idle time rose by $0.74 \%$ when the WBGT was increased by $1{ }^{\circ} \mathrm{C}(\mathrm{Li}$ et al. 2016). Using an econometric approach, Zhang et al. (2018) also estimated the effects of temperature on firm-level TFP, factor inputs, and outputs in Chinese manufacturing plants for 1998-2017 and predicted that in the absence of additional adaptation measures, Chinese manufacturing output would fall by $12 \%$ by the middle of the twenty-first century.

For the future, Coffel et al. (2017) estimated that exposure to WBGTs higher than those of recent heatwaves may increase five- to tenfold by 2070-2080 under RCP4.5 and RCP8.5, and under RCP8.5, exposure to WBGTs over $35{ }^{\circ} \mathrm{C}$ could amount to over one million person-days per year by 2080. Matthews et al. (2017) investigated the relationship between heat stress, measured by the heat index (see Anderson et al. 2013) and temperature and found that the relationship is nonlinear. They also suggested that under a middle-range population growth scenario with global warming of only $1.5^{\circ} \mathrm{C}$, double the number of megacities could become heatstressed by 2050, meaning that 350 million more people would be faced with dangerous heat conditions. Kjellstrom et al. (2009b), the earliest study to investigate this topic on a global scale, investigated the relationship between work capacity and climate conditions (measured by WBGT) and estimated the future loss of work capacity caused by climate change for various work intensities. They showed that the greatest absolute losses of work capacity would be in Southeast Asia, Latin and Central America, and the Caribbean (11-27\%) for the SRES A2 scenario.

Dunne et al. (2013) also predicted that labor capacity would reduce further to $80 \%$ during peak months by 2050 and to less than $40 \%$ by 2200 under RCP 8.5 , with most tropical and mid-latitude zones experiencing extreme heat stress. Under $2{ }^{\circ} \mathrm{C}$ target scenarios, this reduction was likely to be smaller, but the labor capacity would still be lower than historical levels. Kjellstrom et al. (2016) found that $30-40 \%$ of work capacity during the daylight working hours would be lost by 2085 in some areas for RCP8.5. The outdoor labor capacity during the 2090s would be 0.54 under the highest emission 
scenario, and the workday would have to be shifted to 5.7 hours earlier to maintain the labor capacity of the base-year level (Takakura et al. 2018). Reducing work intensity or increasing the frequency of short breaks are effective measures for the prevention of heat-related effects (Kjellstrom et al. 2009b; National Institute for Occupational Safety and Health 2016). However, such interventions reduce work hours and labor productivity (Kjellstrom et al. 2009a; Dunne et al. 2013; SuzukiParker and Kusaka 2016; Donadelli et al. 2017; Takakura et al. 2017) and result in economic losses (Roson and Sartori 2016; Donadelli et al. 2017; Takakura et al. 2017; Rezai et al. 2018; Zhang et al. 2018). Many studies have reported an impact of temperature and climate change on socio-economic activities via changes in labor productivity (Kjellstrom et al. 2009b; Hsiang 2010; Roson and van der Mensbrugghe 2012; Dunne et al. 2013; Kjellstrom et al. 2016; Roson and Sartori 2016; Suzuki-Parker and Kusaka 2016; Takakura et al. 2017, 2018; Matsumoto 2019).

Using a CGE model with a BAU scenario, Roson and van der Mensbrugghe (2012) projected GDP losses of up to $6 \%$ from the decrease in labor productivity in most regions except Europe, which exhibited an increase in GDP by $<1 \%$. In similar research, Roson and Sartori (2016) found lowered labor productivity for the agricultural sector, which faced a mean variation of -2.52 to $17.48 \%$ (for $1-5{ }^{\circ} \mathrm{C}$ warming), than the manufacturing and service sectors.

Using a CGE model, Takakura et al. (2017) found that total worldwide GDP losses in 2100 would be around $2.6-4.0 \%{ }^{21}$ for no-mitigation scenarios but that these losses would be less than $0.5 \%$ if the $2{ }^{\circ} \mathrm{C}$ climate change target was achieved ${ }^{22}$. Even with the introduction of additional adaptation measures, GDP was still projected to suffer severe losses under high-emission scenarios (e.g., 1.0-2.4\% ${ }^{23}$ under the RCP8.5 scenario) (Takakura et al. 2018). Another CGE study found that total GDP would fall by $0.5-0.9 \%{ }^{24}$ globally in 2100 under the BAU scenario, although this impact of climate change would differ by region (from +0.16 to $-5.92 \%$ ). Moreover, the impact on $\mathrm{CO}_{2}$ emissions was predicted to be smaller than the impact on GDP $(-0.25 \text { to }-0.45 \%)^{24}$, and that on temperature was slight (Matsumoto 2019). As another example, using an IAM (including CGE), Roson and van der Mensbrugghe (2012) reported 1.8\% and

\footnotetext{
${ }^{21}$ For RCP8.5 with SSPs $1-3$.

${ }^{22}$ Takakura et al. (2017) also reported that the relationship between GDP losses and the rise in global average temperature was roughly linear.

${ }^{23}$ Among four GCMs.

${ }^{24}$ Considering the uncertainty in climate parameters (17th, 50th, and 83rd percentiles are used).
}

4.6\% GDP loss for 2050 and 2100, respectively due to the change in labor productivity.

Day et al. (2019) summarized the adaptation options into three categories: technical (e.g., air conditioning, ventilation, shading), infrastructural (climate-smart society, economic shift, early warning, education, monitoring), and behavioral (work choice, time shift, individual heat-reducing activities) adaptation measures.

\subsubsection{Diseases and other health issues}

Climate change has been identified as potentially the most significant global health threat of the twenty-first century (Costello 2009), and it is expected to increase health risks due to increases in the frequency and magnitude of extreme weather events, decreases in air and water quality, and a rise in food-borne, vector-borne, and zoonotic diseases (Séguin 2008; Berry et al. 2014).

For example, Ebi et al. (2017) presented a range of strategies for the detection and attribution analysis of the health impacts of climate change. They discussed three case studies (i.e., heatwave-related deaths, the emergence of Lyme disease in Canada, and Vibrio emergence in the Baltic Sea) and concluded that a proportion of climate-sensitive health outcomes can be attributed to climate change. For mosquito-borne diseases, Mordecai et al. (2019) analyzed 11 pathogens transmitted by 15 different mosquito species, including globally important diseases such as malaria, dengue, and Zika, and found that transmission varied strongly and unimodally with temperature, peaking at $23-29{ }^{\circ} \mathrm{C}$ and declining to zero at $9-23{ }^{\circ} \mathrm{C}$ and $32-38{ }^{\circ} \mathrm{C}$. These effects of temperature on transmission varied between mosquito and parasite species; for example, of the tropical pathogens investigated, malaria and Ross River virus had the lowest thermal optima $\left(25-26^{\circ} \mathrm{C}\right)$, while dengue and Zika viruses had the highest $\left(29^{\circ} \mathrm{C}\right)$.

For future change, Honda et al. (2014) evaluated the heat-related excess mortality arising from climate change under the SRES A1B scenario using a distributed lag nonlinear model. They found that Asia was most vulnerable and that, in some regions, heat-related excess deaths would account for $0.6 \%$ of all deaths. Healthcare facilities are thus vital to the management of climatechange-induced health impacts. The increase in the frequency and magnitude of extreme weather events caused by climate change is expected to negatively impact healthcare facilities (Paterson et al. 2014).

Because of climate change, vector-borne diseases can spread to new areas. However, even though initial projections suggested future increases in the geographic range of infectious diseases, more recent models now predict range shifts in disease distributions, with little net increase in area (Lafferty 2009). It is also argued that there was little evidence that climate change had favored 
infectious diseases and that many factors can affect infectious diseases, some of which may overshadow the effects of the climate (Lafferty 2009). For example, Béguin et al. (2011) projected that, for the SRES A1B scenario, climate change would have a much weaker effect on malaria than would the increase in GDP per capita. For vector-borne diseases, the responses of both pathogens and vectors to climate change are important. Tol (2002a) estimated that $1{ }^{\circ} \mathrm{C}$ warming will globally cause a decrease in deaths by 56,000 but a significant increase in South and Southeast Asia and Africa.

Heat-related excess mortality and occupational health cost are two main factors of impact of warming for all four RCPs (Takakura et al. 2019). A study on the economy-wide impacts of climate change on human health using a CGE model found, for the SRES B1 scenario in 2050, that climate-change-induced health impacts range from $+0.08 \%$ to $-0.07 \%{ }^{25}$ of GDP and from $+0.13 \%$ to $-0.18 \%{ }^{25}$ of $\mathrm{CO}_{2}$ emissions (Bosello et al. 2006). Another CGE model-based study, Hasegawa et al. (2016a), evaluated the impact of climate change on human health via undernourishment based on two economic measures. These were (1) changes in morbidity and mortality due to nine diseases caused by being underweight as a child, which affect the labor force, population, and demand for healthcare, and (2) the value of lives lost and willingness to pay to reduce the risk. They showed that the economic valuation of healthy lives lost due to undernourishment in response to climate change under a pessimistic scenario based on SSP3 and RCP8.5 was around $-0.4-0.0 \%{ }^{26}$ of global GDP in 2100 , although this differed by region (ranging from 4.0-0.0\%). They also showed that global economic losses associated with the effects of additional health expenditure and the decrease in the labor force due to undernourishment caused by climate change were - 0.1$0.0 \%{ }^{27}$ of GDP and $-0.2-0.0 \%{ }^{27}$ of household consumption, respectively (RCP8.5/SSP3, in 2100). Nordhaus and Boyer (1999) estimated the damage of $2.5^{\circ} \mathrm{C}$ warming as $0.10 \%$ (output weighted) or $0.56 \%$ (population weighted $)^{28}$ of GDP.

As adaptation measures for the increase in infectious diseases, the following are recommended: (1) further research on the relation between climate change and infectious diseases, (2) improvement of the prediction of the spatial-temporal process of climate change and the associated shifts in infectious diseases at various spatial and temporal scales, and (3) establishment of locally effective

\footnotetext{
${ }^{25}$ Depending on the region.

${ }^{26}$ Mainly from the choice of values of life. Climate and crop model uncertainty is also included.

${ }^{27}$ Climate and crop model uncertainty.

${ }^{28}$ The difference indicates that damages are concentrated in lowincome regions.
}

early warning systems for the health effects caused by climate change (Wu et al. 2016).

\subsection{Industry and related economic activity}

This section covers a wide range of economic activities related to industry, including energy supply and demand, infrastructure, insurance and finance, tourism, and transportation. It was difficult to include manufacturing as a sub-section, as only qualitative assessments of the supply chain were available (e.g., Tenggren et al. 2020).

\subsubsection{Energy sector}

The energy sector is relatively sensitive to climate change in terms of both supply and demand. Vulnerable portions on the supply side include thermoelectric power, hydropower, and renewable sources such as wind energy. On the other hand, significant variation exists in energy demand-particularly related to the energy used for thermal comfort, including heating, cooling, and dehumidification-between different latitudes. Thus, colder areas may not require as much energy for warming as temperatures increase, while warmer regions will use more for cooling (de Cian et al. 2013). In turn, efforts on climate change mitigation could induce technological development, which positively affects the economy (Matsumoto 2011a, 2011b, 2012).

For the supply side, the water stress resulting from global warming can lead to insufficient water availability, which in turn reduces thermoelectric and nuclear power generation. Similarly, hydropower is expected to exhibit more seasonal variability due to climate change; particularly, in summer, energy generation would decline by around 14\% (RCP4.5, 2091-2100) compared with the present generation, which would be a matter of concern for the energy managers (Chilkoti et al. 2017). However, globally, no notable aggregated impacts on GDP are expected in the future when comparing low and high physical impact scenarios, although substantial differences will be observed between regions ${ }^{29}$. In addition, because climate change affects wind speeds, it is likely to influence the generation of wind energy ${ }^{30}$ (Pryor et al. 2012).

For the demand side, it is indicated that urban economies in developed (developing) countries need to exhibit a cooling electricity response of $35-90 \mathrm{~W} /$

\footnotetext{
${ }^{29}$ For example, the maximum achievable hydropower generation might range from - 37\% in the Middle East to approximately 20\% in the former Soviet Union under RCP2.6 in 2100 compared to the level of 1960-1989, and for GDP, it might range from - $0.11 \%$ in Brazil to approximately $0.21 \%$ in the former Soviet Union in the RCP2.6 scenario in 2100 relative to the scenario without considering the physical climate impacts (Zhou et al. 2018a).

${ }^{30}$ For example, Pryor et al. (2012) presented evidence of lower intense wind speeds, particularly in the western regions of the US in 20412062, but expected no differences in extreme wind speeds relative to 1979-2000 under SRES A2.
} 
${ }^{\circ} \mathrm{C}\left(2-9 \mathrm{~W} /{ }^{\circ} \mathrm{C}\right)^{31}$ per capita as a cooling electricity above room temperature for cooling (interquartile range of estimates), with the difference attributed to the adoption of air conditioning. For heating, the relation becomes less clear, as non-electricity-based equipment can be used (Waite et al. 2017). Because of the rising household incomes and global warming, the increasing adoption of air conditioning by middleincome countries is confirmed by another study, since most of the homes in high-income countries are already equipped with air-conditioning systems (Davis and Gertler 2015). Globally, heating energy demand will decrease by $34 \%$ and cooling demand will increase by $72 \%$ by 2100 , and the impact on global $\mathrm{CO}_{2}$ emissions is small for heating but significant (some $1.6 \mathrm{GtCO}_{2}$ in 2100) for cooling based on a reference scenario (Isaac and van Vuuren 2009). Under the SRES A1B scenario in 2050, changes in heating and cooling energy demands are projected to be $30 \%$ and $+73 \%$, respectively, relative to the situation in 2050 in the absence of climate change (Arnell et al. 2016a). While the percentage changes in heating requirements are not significantly different among the SRES A1B, A2, and B2 scenarios, the percentage changes regarding cooling requirements show significant differences (up to around 20\%) in the A2 and B2 scenarios compared with the A1B scenario (Arnell et al. 2016b). As with the economic costs, the changes in the global heating and cooling cost per 1 ${ }^{\circ} \mathrm{C}$ warming are estimated to be -120 and 75 billion USD, respectively (Tol 2002a). The impact on GDP is expected to be $-0.34 \%$ for RCP8.5 due to changes in energy demand for space heating and cooling systems, and most of them are attributable to additional investment cost for introducing heating and cooling technology (Hasegawa et al. 2016b). The monetized impacts of global warming on cooling/heating demand are globally negative for all four RCPs under the socio-economic assumptions of SSP1-5 (Takakura et al. 2019).

Adaptation options, such as increasing plant efficiency and replacing system types and fuel switches, are mentioned as effective alternatives to reduce the assessed vulnerability to changing climate and freshwater resources (van Vliet et al. 2016). Behrens et al. (2017) compared four adaptation strategies of power generation to water supply: further switch to seawater cooling, retrofitting of plants to dry air cooling, early retirement of existing power plants, and cancelation of planned plants in favor of renewables. They found that increased future seawater cooling would ease some pressures, highlighting the need for an integrated, basin-level

\footnotetext{
${ }^{31}$ Depending on the city.
}

approach in energy and water policy. Some other options are mentioned by Rübbelke and Vögele (2011), van Vliet et al. (2012), Zhou et al. (2018b), and Davide et al. (2018), who analyzed the adaptation options regarding water (conservation/harvesting/recycling/distribution, irrigation [and its efficiency], desalinization), infrastructure (transport, electrification, multipurpose dams), renewable energy, energy efficiency, health (early warning systems, medical services), living conditions (buildings, heating/cooling, water heating), information and education, and food (food storage, livestock) under the Sustainable Development Goals ${ }^{32}$.

\subsubsection{Infrastructure}

Energy, transport, industrial, and social infrastructure is usually constructed to have a long lifespan, meaning it can potentially be vulnerable to long-term changes in the climate.

Here, as we could not find global assessments, we mention some city/country-scale analyses. The costs associated with damage to critical infrastructure due to climate extremes in Europe could be three times higher than the figure in 1981-2010 of 3.4 billion EUR per year by the 2020s, six times higher by the 2050s, and more than 10 times higher by 2100 with the assumed biascorrected climate projections under the SRES A1B emissions scenario (Forzieri et al. 2018). It has also been reported that greater damage and/or the earlier failure of pavement in the US is expected under the RCP8.5 and 4.5 climate change scenarios (Gudipudi et al. 2017). Moreover, the incorrect selection of materials for US pavement infrastructure could lead to additional costs of approximately $13.6,19.0$, and 21.8 billion USD by 2010 , 2040, and 2070, respectively, under RCP4.5, increasing to $14.5,26.3$, and 35.8 USD billion, respectively under RCP8.5 (Underwood et al. 2017). In addition, from 2015 to 2099, damage to Alaskan public infrastructure would cost approximately 5.5 billion (2015 USD, 3\% discount) under RCP8.5 and 4.2 billion USD under RCP4.5, most of which is for roads and buildings ${ }^{33}$ (Melvin et al. 2017).

Here, the potential adaptation options considered for infrastructure include increased diameter culverts and drainage systems (against flooding in roads and runways), base-layer modification and thermosyphon installation (permafrost thaw, roads, and runways), modified binder/sealant application, and base-layer strengthening (precipitation, roads, and runways), increased diameter roof drainage systems (precipitation, buildings), and

\footnotetext{
${ }^{32}$ Furthermore, they proposed a framework connecting adaptation, mitigation, and sustainable development.

${ }^{33}$ However, the costs are reduced to 2.9 and 2.3 billion USD when proactive adaptation is applied for the same scenarios (Melvin et al. 2017).
} 
base-layer modification and thermosyphon installation (permafrost thaw, railroads).

\subsubsection{Tourism and transportation}

Weather and climate conditions are important determinants of travel times and destinations for leisure and recreation. Thus, global warming can have a significant impact on the tourism industry.

For the present status, the existing literature has found that cold-weather activities may be at greater risk due to climate change, especially skiing (Steiger et al. 2019), while there might be increased opportunities for warmweather activities (Hewer and Gough 2018). Another survey on the weather preferences of French tourists revealed that tourists generally show a high tolerance for heat and even to heatwaves, while rainy conditions are a disincentive to travel (Dubois et al. 2016).

For the future projections, tourism will grow in the future, and the influence of changes in population and income is expected to be larger than that from climate change (Hamilton et al. 2005). It is important to note, however, that there are significant gaps in knowledge when predicting future tourism trends, including outdated climate science, climate models, and climate change scenarios; inconsistent assessments between different regions; and a lack of assessment methods for weather sensitivity and potential impacts of climate change for outdoor recreation and tourism activities (Hewer and Gough 2018).

The transportation sector also faces indirect impacts of climate change. Obradovich and Rahwan (2019) showed that moving from freezing temperatures to 30 ${ }^{\circ} \mathrm{C}$ increased vehicle miles traveled by over $10 \%$ in the US and increased public transit trips by nearly $15 \%$, while temperatures beyond $30{ }^{\circ} \mathrm{C}$ had little influence on these measures. As a result, over 1 trillion cumulative vehicle miles traveled and 6 billion public transit trips in the US are expected due to global warming under RCP8.5. In contrast, climate change could also lower water levels, making traditional river transport less reliable, as in Canada's Mackenzie River (Du et al. 2017). Global warming melts sea ice in the Arctic, increasing accessibility for shipping ( $\mathrm{Ng}$ et al. 2018), and the risks facing Arctic aviation and marine transportation could be assessed using the Arctic Climate Change Vulnerability Index, combining exposure, sensitivity, and adaptive capacity (Debortoli et al. 2019). The transportation sector is also increasingly vulnerable to climate change in coastal areas, islands, and other places exposed to flooding $^{34}$. Shifts in tourism patterns as well as agricultural

\footnotetext{
${ }^{34}$ For example, in Caribbean Small Island Developing States, a rise in temperature could disrupt transport operations, and some airports may be affected by more frequent coastal inundation due to climate change (Monioudi et al. 2018).
}

production may also affect passenger and freight transport indirectly (Koetse and Rietveld 2009).

Regarding the potential economic impacts or the resulting $\mathrm{CO}_{2}$ emissions, Berrittella et al. (2006), using a world CGE model under the SRES B1 scenario, evaluated the economic implications of climate-changeinduced variation in tourism demand and predicted regional variation in GDP of $-0.3-0.5 \%{ }^{35}$ and $\mathrm{CO}_{2}$ emissions of $-0.001-0 \%{ }^{35}$ in 2050. As an example of impacts through disasters, disruption costs in Newcastle upon Tyne in the United Kingdom due to a 1-in-50-year event leading to pluvial flooding could be $66 \%$ higher by the 2080s, although interventions could lead to a $32 \%$ reduction in travel delays (Pregnolato et al. 2017).

For adaptation, Scott and Becken (2010) pointed out that climate change adaptation research on tourism is significantly delayed compared with other economic sectors, with low awareness of climate change and less strategic planning in anticipation of future changes in climate. They also claim that the tourism industry has shown its relatively high adaptive capacity in the sector to the shocks but that knowledge of the capacity to cope with future climate and the broader environmental impacts and societal ramifications remains insufficient. Scott et al. (2012) listed technical, managerial, policy, research, educational, and behavioral adaptation measures for tourism businesses and emphasized the climate change challenges that exist in tourism to provide implications and suggestions for policy-makers to reduce the climate-related risks or to take the advantage of relevant opportunities.

\subsubsection{Insurance and finance}

Increased disasters will lead to insurance claims, and thus, the premiums should be raised. It is pointed out that climate change can have negative impacts on the affordability and availability of insurance, slow the growth of the industry, and become a greater burden to governments and individuals (Mills 2005).

As a past example, Cannon et al. (2020), in their analysis of post-Katrina New Orleans in the US, argued that uninsured or underinsured homes in cities prone to flooding have a greater risk of facing both flooding and higher insurance premiums due to climate change.

A future projection of flood insurance premiums in the Netherlands concluded that the premiums may increase considerably as a result of socio-economic and climate changes but that this increase would be very region-specific (Aerts and Botzen 2011). It is also reported that the expected "climate value at risk" for global financial assets was $1.8 \%$ under a BAU emissions scenario (16.9\% for the 99 th percentile), falling to $1.2 \%$

\footnotetext{
${ }^{35}$ For eight regions.
} 
(9.2\% for the 99th percentile) under a $2{ }^{\circ} \mathrm{C}$ scenario (Dietz et al. 2016). A study using an agent-based climate-macroeconomic model predicted that banking crises would be more frequent in the face of climate change (by 26-248\%) and that propping up insolvent banks would lead to an annual fiscal burden of around $5-15 \%$ of GDP, doubling the ratio of public debt to GDP (Lamperti et al. 2019). Dafermos et al. (2018) argued that the liquidity of firms is likely to deteriorate, leading to higher default rates and damaging both financial and non-financial corporate sectors. They also predicted that climate-induced financial instability may have a negative influence on credit expansion, worsening the overall impact on economic activity, and that introducing a green corporate quantitative easing program could reduce this instability and slow global warming.

In the longer term, due to the decreased availability and affordability of insurance coverage, insufficient adaptation in areas of increasing risk could threaten the concept of insurability itself (Herweijer et al. 2009). In developing countries (Linnerooth-Bayer and Mechler 2006), particularly for agriculture (Nnadi et al. 2013), insurance will work as an adaptation measure.

\subsection{Migration and civil/international conflict}

It is commonly assumed that climate change will heavily impact patterns of human migration and conflict via shortages of resources (e.g., food, water), although it is difficult to assess the economic damage arising from this. In addition, at present, it is difficult to project future trends in the frequency and scale of migration and conflicts.

\subsubsection{Migration}

A global survey found that climatic conditions strongly influenced migration for the period 2011-2015 by increasing the severity of drought and the chances of armed conflict (Abel et al. 2019).

The following studies are examples of regional migration in the past. A study on the Indian Sundarbans assessed the environmental, economic, and social factors that spurred migration and identified environmental factors as the most important (Guha and Roy 2016). In rural Ethiopia, it was indicated that the migration of men for employment increased with drought and that land-poor households were most vulnerable, while the movement of women for marriage decreased with drought (Gray and Mueller 2012). Similarly, in Burkina Faso, Henry et al. (2004) suggested that residents of drier regions were more likely to participate in both temporary and permanent migration to other rural areas and that short-term drought tended to increase long-term migration to rural areas and decrease short-term migration to distant destinations. In rural Pakistan, Mueller et al. (2014) found that flooding, a climate shock that requires extensive relief efforts, had a modest to insignificant impact on migration, while heat stress consistently increased the long-term migration of men when no relief systems were introduced, driven by the negative effect on farm and non-farm incomes. On the other hand, Shayegh (2017) suggested the possibility that the migration of skilled people due to climate change may reduce local income inequality.

Land degradation due to climate variability is an indirect effect that can trigger migration. For example, it is suggested that land scarcity and degradation are linked to out-migration in general and to migration from the forest frontier of northern Guatemala in particular (López-Carr 2012). Good soil quality significantly reduces migration, particularly temporary labor migration, in Kenya but marginally increases migration in Uganda (Gray 2011). In low-lying island countries, there is growing consensus that international migration should be planned for and coordinated (Hauer et al. 2020). In Malé, the capital of the Maldives, more than $50 \%$ of respondents believed that future SLR was a serious challenge at the national level and they considered migration to other countries as a potential option in response to this, although many other factors (e.g., cultural, religious, economic, and social factors) are believed to play an important role in migration-related decision-making (Stojanov et al. 2017).

McLeman and Smit (2006) and Tacoli (2009) argued that migration could be an adaptation measure; labor migration could be a particularly good opportunity to utilize migration to promote adaptation to climate change (Barnett and Webber 2009). For the Maldives, the development of artificial islands (such as Hulhumalé) and coral propagation around existing islands are mentioned as hard and soft adaptation strategies for climate change (Sovacool 2012).

\subsubsection{Civil and international conflict}

Water and food shortages, and significant deterioration of the living environment caused by climate change, can in turn lead to raiding or conflicts. For the past, a survey on global- and country-scale analyses reported that an increase of 1 standard deviation in temperature or rainfall raises interpersonal violence and intergroup conflict by $4 \%$ and $14 \%$, respectively (Hsiang et al. 2013), while policymakers have been warned against drawing general conclusions from current data (Bernauer et al. 2012; Hendrix 2017; Adams et al. 2018). Another global survey pointed out that in western Asia in the period 20102012, when many countries were undergoing political transformation, the effect of climate on conflict occurrence was confirmed (Abel et al. 2019). It is also reported that the risk of armed conflict was greater in the presence of climate-related natural disasters in countries 
characterized by ethnic division (Schleussner et al. 2016). Moreover, it is reported that transboundary water disputes are also potential flashpoints for conflict in a number of regions around the world, with climate change and associated variability in the weather increasing the uncertainty surrounding access to clean water (Kreamer 2012). The global association between extreme weather events and civil conflict was also observed for droughts in Somalia ${ }^{36}$ (Maystadt and Ecker 2014). In the Horn of Africa, Solomon et al. (2018) demonstrated that conflict had a strongly negative impact on the environment and that climate variability exacerbated the impact of this conflict.

For future warming, experts agree that the climate can affect organized armed domestic conflict but claim that other drivers, such as low socio-economic development and poor state performance, are more influential. On average, for the $2{ }^{\circ} \mathrm{C}$ scenario, the number of experts expecting "negligible change" is similar to the total of those selecting "moderate increase" and "substantial change," while for the $4{ }^{\circ} \mathrm{C}$ scenario, the numbers of experts selecting the three answers are similar to each other (Mach et al. 2019).

For adaptation, a research study on Bangladesh mentioned the possibility that adaptation projects can potentially harm others and intensify violent conflicts and claimed that the project planners and practitioners need to become more aware of this fact (Sovacool 2018). Another study on Kenyan drylands also argued that consideration of the political dimensions of local adaptation is needed for climate change adaptation policies to be successful and that conflict is not an external factor inhibiting local adaptation strategies but a part of the adaptation process (Eriksen and Lind 2009). On the other hand, also in (northern) Kenya, it is argued that promoting adaptation includes reducing the level of conflict and insecurity. In addition, the following three key recommendations are mentioned: strengthening of intercommunal conflict prevention and resolution mechanisms, establishing a regional framework that promotes pastoral mobility across international borders, and reducing the availability of small arms through intergovernmental agreements and harmonized disarmament efforts (Schilling et al. 2011).

\section{Discussion: interactive coupling of Earth and human systems}

We have reviewed a plethora of existing studies on representative important sectors and processes. While we

\footnotetext{
${ }^{36}$ Using the data of 1997-2009, Maystadt and Ecker (2014) also estimated that an increase of 1 standard deviation in drought intensity and length in Somalia would increase the likelihood of conflict by $62 \%$, with conflict arising from changes in livestock prices and the establishment of livestock markets.
}

were of course unable to cover all or most studies, we were able to review a considerable number of excellent studies. In addition, it is also possible that existing studies contain gaps and/or biased results. Thus, although in this section, we attempt to draw some conclusions from the review performed in the previous section, we need to do so carefully. In addition, we need to be careful in comparing studies using the relatively simple damage function approach and those using process-based modeling.

As reviewed in Section 2, many processes and sectors experience non-negligible physical or ecological impacts due to climate change. However, identifying those processes/sectors that are most important in terms of the interaction between Earth and socio-economic systems is difficult, because there is no established approach for comparing these processes/sectors. The most effective strategy for evaluating the potential feedbacks to the climate could be to compare consequent changes in GHG emissions, but very few studies have addressed this. Thus, we compared the impact on GDP, thinking that GHG is roughly proportional to GDP (i.e., assuming that other conditions are not affected by a GDP reduction of up to $1 \%$ ). Table 2 summarizes previous quantitative assessments of the impact on GHG emissions and GDP. Many of the studies cited in this table employed a CGE model, meaning that the impacts were evaluated after the propagation of the shock for the economy as a whole. The second column from the right indicates the importance of the process/sector in terms of its GDP or GHG impacts, and the rightmost column displays the feasibility based on the authors' judgment.

For GHG emissions, among the sectors for which literature is available, those related to land productivity (i.e., cropland and pasture) have the strongest effect. These sectors have a relatively low impact on GDP, but the resultant change in land cover is $2-3 \%{ }^{37}$, and that in land-use emission is $8-13 \%^{38}$ (Bajželj and Richards 2014). In addition, changes in land cover can influence the physics of the land surface, including albedo and evapotranspiration, as well as carbon absorption. Changes in land surface conditions can affect fire occurrence, which can lead to other physical and biochemical changes. Other studies have also suggested the importance of changes in land cover and management (Brovkin et al. 2013; Luyssaert et al. 2014; Harper et al. 2018). Hence, this sector should not be ignored when considering the interaction between Earth and human systems. In modeling, cropland allocation is typically determined using the suitability based on land conditions (Ramankutty et al. 2002; Di Vittorio et al. 2016). Areas with high

\footnotetext{
${ }^{37}$ SRES B1 (2\%) and A1 (3\%) (relative to the no climate change case).

${ }^{38}$ SRES B1 (8\%) and A1 (13\%) (relative to the no climate change case).
} 
Table 2 GHG emissions and GDP changes caused by each process and sector

\begin{tabular}{|c|c|c|c|c|c|c|}
\hline Section & $\begin{array}{l}\text { Process/ } \\
\text { sector }\end{array}$ & $\begin{array}{l}\mathrm{CO}_{2} / \mathrm{GHG} \text { emission reduction (\%) } \\
\text { (negative value means } \mathrm{GHG} \\
\text { emission increase) }\end{array}$ & $\begin{array}{l}\text { GDP loss (\%) } \\
\text { (negative value } \\
\text { means GDP } \\
\text { growth) }\end{array}$ & Remarks & $\begin{array}{l}\text { Importance (in } \\
\text { terms of GHG or } \\
\text { GDP impacts)* }\end{array}$ & $\begin{array}{l}\text { Feasibility } \\
\text { of } \\
\text { modeling** }\end{array}$ \\
\hline 2.2 .1 & Agriculture & 3 and $5^{a}$ & $\begin{array}{l}0.02-0.06^{\mathrm{b}}, 0.13 \\
(0.17)^{\mathrm{c}}, 0.06^{\mathrm{d}}\end{array}$ & $\begin{array}{l}\text { Feedback via land cover change } \\
\text { (albedo, carbon flux, etc.) }\end{array}$ & $\mathrm{H}$ & $E$ \\
\hline 2.2 .2 & Livestock & & $0.01^{e}$ & $\begin{array}{l}\text { Feedback via land cover change } \\
\text { and changes in livestock number }\end{array}$ & M & E \\
\hline 2.3 & $\begin{array}{l}\text { Water } \\
\text { resources }\end{array}$ & - & $0.6^{d}$ & - & M & M \\
\hline 2.4 & SLR & $0.0-0.15^{f},-0.04-0.02^{g}$ & $\begin{array}{l}0.32(0.12)^{c}, 0.0- \\
0.1^{\dagger}, 0.0-0.03^{g}\end{array}$ & Life-threatening & M & M \\
\hline 2.5 & $\begin{array}{l}\text { Natural } \\
\text { disasters }\end{array}$ & - & $\begin{array}{l}\text { Negligible }{ }^{\mathrm{h}}, 0- \\
0.2^{\mathrm{i}}\end{array}$ & Life-threatening & M & M \\
\hline 2.6 & $\begin{array}{l}\text { Ecosystem } \\
\text { services }\end{array}$ & - & $\begin{array}{l}0.17(0.10)^{\mathrm{c} 1} \\
0.4^{\mathrm{d} 1}\end{array}$ & - & M & D \\
\hline 2.7 .1 & $\begin{array}{l}\text { Labor } \\
\text { productivity }\end{array}$ & $0.25-0.45^{j}$ & $\begin{array}{l}2.6^{6}-4.0^{\mathrm{k}}, 0.5-0.9^{\mathrm{j}} \\
1.8^{\mathrm{l}}, 4.6^{\prime}, 1.0-2.4^{\mathrm{m}}\end{array}$ & - & $\mathrm{H}$ & E \\
\hline 2.7 .2 & $\begin{array}{l}\text { Other health } \\
\text { issues }\end{array}$ & $-0.13-0.18^{g}$ & $\begin{array}{l}0.10(0.56)^{c}, 0.0- \\
0.1^{n},-0.08- \\
0.07^{g}\end{array}$ & $\begin{array}{l}\text { For VSL }{ }^{* * *} \text { (mortality): } 0.0-0.4 \%{ }^{n}, \\
0.17 \% /{ }^{\circ} \mathrm{C}^{c, O}\end{array}$ & M & M \\
\hline 2.8 .1 & Energy & $0(2050),-1.1(2100)^{\mathrm{p}}$ & $\begin{array}{l}0.2(0.3)^{\mathrm{d} 2}, 0.0- \\
0.2^{\mathrm{h}}, 0.34(0.03)^{\mathrm{q}}\end{array}$ & $\begin{array}{l}\text { No notable aggregated impacts } \\
(\text { supply })^{r}\end{array}$ & M & M \\
\hline 2.8 .2 & Infrastructure & - & $\begin{array}{l}0.01-0.02^{5}(E U) \\
0.1-0.2^{t}(U S)\end{array}$ & - & L & M \\
\hline 2.8 .3 & $\begin{array}{l}\text { Tourism and } \\
\text { transportation }\end{array}$ & $0-0.001^{\mathrm{u}}$ & $-0.5-0.3^{\mathrm{u}}$ & Almost no change as a whole & L & D \\
\hline 2.8 .4 & $\begin{array}{l}\text { Insurance } \\
\text { and finance }\end{array}$ & - & - & $\begin{array}{l}5-15 \% \text { needed to rescue } \\
\text { insolvent banks }{ }^{\vee}\end{array}$ & $\mathrm{H}$ & $\mathrm{D}$ \\
\hline 2.9 .1 & Migration & - & - & Welfare impact & - & $D$ \\
\hline 2.9 .2 & Conflict & - & - & Life-threatening & - & $D$ \\
\hline
\end{tabular}

*High (H): > 1\%, Medium (M): 0.1-1\%, Low (L): < 0.1\%

**Easy (E), Medium (M), Difficult (D). This is based on the authors' judgment considering the modeling framework

***Value of statistical life

${ }^{a}$ Bajželj and Richards (2014): 5 and 3 for SRES A1 and B1 scenarios

${ }^{b}$ Fujimori et al. (2018), RCP8.5, SSP 2, 2100, CGE

${ }^{\mathrm{C}}$ Nordhaus and Boyer (1999) output weighted (population weighted) for $2.5^{\circ} \mathrm{C}$ warming, CGE; c1: settlement and ecosystem were merged in their evaluation

${ }^{\mathrm{d}}$ Tol (2002b), 2050 (central case); d1: for ecosystem; d2: 2050 (2100): demand for heating [0.4(0.7)] + for cooling [- 0.2(- 0.4)]

e Boone et al. (2018) divided by GDP in the IIASA SSP dataset (https://tntcat.iiasa.ac.at/SspDb/dsd)

fBigano et al. (2008), 2050 SLR of $25 \mathrm{~cm}$, CGE (range shows regional difference)

${ }^{9}$ Bosello et al. (2006), CGE (range shows regional difference)

hTakakura et al. (2019), CGE; e1: among the scenarios (RCP-SSP)

'Mendelsohn et al. (2012)

jMatsumoto (2019) BAU, 2100, CGE

kTakakura et al. (2017) BAU, 2100, CGE

'Roson and van der Mensbrugghe (2012). 1.8\% and 4.6\% for 2050 and 2100 (IAM including CGE)

m Takakura et al. (2018): RCP8.5 with reasonable time shift $(<3 \mathrm{~h})$ as adaptation

${ }^{n}$ Hasegawa et al. (2016a) RCP8.5/2.6, 2100, CGE

${ }^{\circ}$ Bosworth et al. (2017) for VSL $(7 \times 10$ million USD/person)

PIsaac and van Vuuren (2009): 0 (at 2050) and 0.32 (at 2100) PgC (their Fig. 10), the latter of which was divided by 28.8 PgC of RCP8.5 in place of their reference scenario (of $3.7 \mathrm{~K}$ warming in 2100)

${ }^{\mathrm{q}}$ Hasegawa et al. (2016b) CGE, in 2100 with RCP8.5 (RCP2.6)

'Zhou et al. (2018a) (CGE)

${ }^{\text {s}}$ Forzieri et al. (2018), divided by GDP (http://sres.ciesin.org/final data.html)

tUnderwood et al. (2017), divided by GDP (https://sedac.ciesin.columbia.edu/data/set/sdp-downscaled-gdp-a1a2b1b2-1990-2100/data-download)

uBerrittella et al. (2006), CGE (SRES A1, 2050)

'Lamperti et al. (2019), BAU, agent-based model

- No data from our review

suitability are allocated in order so that the total crop yield (estimated using an agricultural crop yield model) satisfies the food (and biofuel) demands given from another source (e.g., a socio-economic model). The crop type to plant is then chosen to maximize the profit (e.g., Meiyappana et al. 2014; Hasegawa et al. 2017). Models 
could be further improved through model intercomparisons (e.g., Prestele et al. 2016; Lawrence et al. 2016).

The effect of the livestock sector has been assessed to be more moderate than that for the agricultural sector, and an estimated GDP impact of $0.01 \%$. However, raising livestock generates relatively high GHG emissions, particularly $\mathrm{CH}_{4}$ and $\mathrm{N}_{2} \mathrm{O}$ (Herrero et al. 2016b). The manner for modeling this sector is in many cases simpler than that used for cropland (e.g., Yokohata et al. 2020), indicating there is more potential for sophistication. In Bajželj and Richards (2014), total agricultural (including pastoralism) GHG emissions, including net forest cover, tropical pristine forest cover, and land-use change emissions, were estimated as 3\% and 5\% for the SRES B1 and A1 scenarios (relative to the no climate change case), respectively. This is large compared with other sectors/processes (Table 2), and as this sector is a point of contact between humans and natural systems, the sector is considered to be one of the most important in coupling human and Earth system models.

In addition to agriculture and livestock, the impact of labor productivity on GHG emissions appears to be relatively significant $(0.25-0.45 \%)$. Considering that Matsumoto (2019), using a simpler approach, resulted in a smaller GDP impact than Takakura et al. (2017), it is possible that the GHG impact was underestimated in Matsumoto (2019). Considering the difference in numbers reported by these studies, the GHG impact of labor productivity could be comparable with that of the agricultural sector if Takakura et al.'s (2017) model is used. To incorporate this effect, the easiest way is to use the simplified (linearized) relationship between temperature and labor productivity for each of agriculture, manufacturing, and service sectors presented by Roson and Sartori (2016), as attempted by the example in Matsumoto (2019). The energy sector can also have a significant effect, causing a $1 \%$ increase in GHGs, mainly due to increasing cooling demands. In Isaac and van Vuuren (2009), demand was calculated as a product of the number of households who owned air conditioners and the unit energy consumption that was determined with cooling degree days ${ }^{39}$ and income. It should be noted that there could be some inter-sectoral interaction, such as between energy demand and labor productivity (via using air conditioning).

In terms of GDP, finance may have more impact than labor productivity, with Lamperti et al. (2019) reporting that $5-15 \%$ of GDP would be needed to bail out insolvent banks. However, they employed an agent-based economic model to arrive at their

\footnotetext{
${ }^{39}$ Cumulative temperature over $18{ }^{\circ} \mathrm{C}$.
}

estimates; when this type of model is not available, it would be difficult to quantify this effect.

Other processes that have been reported to have potentially large impacts are water resources, SLR and inundation, natural disasters, ecosystem services, disease, and other health issues, although most of these have only been supported by a small number of studies each. Thus, more research is needed for firm conclusions to be drawn. In contrast, infrastructure, tourism, and transportation are predicted to have a relatively small impact. However, it should be noted that a process or sector that has a limited global impact on socio-economic systems does not necessarily have a negligible regional impact. Indeed, from an impact assessment perspective, regional impacts may be more important, although this was not the main focus of the current study. Of the five processes/sectors (i.e., water resources, SLR, natural disasters, ecosystem services, disease, and other health issues), ecosystem services may be the most difficult to model due to their wide variety.

For life-threatening processes such as disease, migration, and conflict, although there are some examples to evaluate the monetary damage assessments (which causes feedbacks to the climate via GDP and then emission changes), it is difficult to assess all the effects to the climate. Here, we presented some examples of other approaches knowing it is difficult to obtain quantitative information on the amount of feedback that could be given to the climate. For disease and health issues, a larger impact was reported when the value of statistical life (VSL) was employed to predict additional mortality, but this does not directly impact GDP, and monetizing the value of human life is controversial. Thus, we may need more discussion when comparing the impact on GDP and the VSL. However, we should not underestimate the importance of processes that are difficult to discuss in terms of their impact on GDP. For example, natural disasters and conflict can expose a large number of people to danger, and migration can have a number of deleterious impacts (e.g., poverty [through the loss of assets], discrimination, and the loss of identity) that may not be easy to monetize. Possibly the most representative example of this may be small Pacific island countries, who stand to lose a significant proportion of their territory due to the effects of climate change. In addition, to incorporate migration and conflict in economic models, more knowledge of their causes and consequences is required. For some studies, cases with adaptation were also evaluated, but originally, the cases without adaptation should be first evaluated and incorporated into the model (in this case, a humanEarth system model), and then, the effects of adaptation should be evaluated using the model. 
Although not mentioned in Section 2 or Table 2, another possible source of large uncertainty would be human behavior. Beckage et al. (2018) showed such a possibility leading to behavioral uncertainty of a comparable magnitude to physical uncertainty. However, the large uncertainty is not a result of the accumulation of many processes but a choice in the equation to calculate for human behavior; three types (linear, logistic, and cubic) of equations were applied despite the fact that the theory of planned behavior generally uses a linear functional form. Thus, we expect follow-up studies.

As noted above, this is a current overview, but as also noted, some sectors' assessments are based on a small number of studies, and in some cases, there are no global assessments on the impact on GDP and GHG emissions. Thus, we need to accumulate more studies for each sector to draw solid conclusions.

\section{Conclusions}

In this study, we reviewed the impacts of climate change on processes and sectors that were selected from a list of impact assessment studies based on their potential to cause feedbacks to the climate. We focused primarily on recent quantitative studies; although it was not possible to review all of these, we reviewed a sufficient number to overview how a specific process/sector is affected by climate change and the extent of its impact on the economy and subsequently the climate by evaluating its relative importance in terms of GHG emissions and GDP. For GHG emissions, we identified land productivity, particularly agriculture, as a key process with the additional benefit of high modeling feasibility, while labor productivity (in terms of both GHG emissions and GDP) and the energy sector (GHG) were also found to play important roles. We also identified water resources, SLR, natural disasters, ecosystem services, and disease and other health issues as having a non-negligible impact on GDP and/or GHG.

To incorporate life-threatening processes such as disease, migration, and conflict, a solely economic impact assessment may be insufficient, because even though they are obviously vulnerable processes, it is difficult to estimate their monetary costs. In addition, the finance sector is likely to have a large impact on GDP, but conventional CGE models may be unable to incorporate this, so more sophisticated models, such as agent-based economic models, should be considered. Based on the results of this review, we intend to look at coupling Earth and socio-economic models in future work.

\section{Abbreviations}

BAU: Business as usual; CGE: Computable general equilibrium; DICE: Dynamic Integrated Climate-Economy (model); EbA: Ecosystem-based adaptation; EMIC: Earth system model of intermediate complexity; ESM: Earth system model; GCM: Global climate model; GDP: Gross domestic product;
GHG: Greenhouse gas; IAM: Integrated assessment model; IPCC: Intergovernmental Panel on Climate Change; RCP: Representative Concentration Pathway; SI: Supplementary information; SLR: Sea level rise; SRES: Special Report on Emission Scenarios; SSP: Shared Socioeconomic Pathway; TCRE: Transient climate response to cumulative carbon emissions; TEEB: The Economics of Ecosystems and Biodiversity; TFP: Total factor productivity; US: United States; USD: US dollar; VSL: Value of statistical life; WBGT: Wet-bulb globe temperature; WCI: Water crowding index; WSI: Water stress index

\section{Supplementary Information}

The online version contains supplementary material available at https://doi. org/10.1186/s40645-021-00418-7.

\section{Additional file 1.}

\section{Acknowledgements}

The authors thank Drs. Kiyoshi Takahashi and Tokuta Yokohata from the National Institute for Environmental Studies, Japan, Dr. Atsushi Kurosawa from the Institute of Applied Energy, and Dr. Kaoru Kakinuma from Shanghai University for their helpful comments on an earlier version of the manuscript. This work was supported by the Integrated Research Program for Advancing Climate Models (TOUGOU) Grant Number JPMXD0717935715 from the Ministry of Education, Culture, Sports, Science and Technology (MEXT), Japan.

\section{Authors' contributions}

All three authors contributed to literature survey. XS wrote the energy, infrastructure, tourism, and transportation parts. KM wrote the human health part. KT wrote all other parts including the Introduction, Discussion, and Conclusion. All authors read and approved the final manuscript.

\section{Authors' information}

All authors are the members of the "Earth - Socioeconomic System Interaction" Team in Theme B: "Sophisticated Earth system model for evaluating emission reductions needed" of the Integrated Research Program for Advancing Climate Models (the TOUGOU program).

\section{Funding}

This work was supported by the Integrated Research Program for Advancing Climate Models (TOUGOU) Grant Number JPMXD0717935715 from the Ministry of Education, Culture, Sports, Science and Technology (MEXT), Japan, and JSPS KAKENHI grant number JP18K11754.

\section{Availability of data and materials \\ Not applicable}

\section{Declarations}

Competing interests

The authors declare that they have no competing interests.

\section{Author details}

${ }^{1}$ Research Institute for Global Change, Japan Agency for Marine-Earth Science and Technology, 3173-25 Showa-machi, Kanazawa-ku, Yokohama 236-0001, Japan. ${ }^{2}$ Faculty of Economics, Toyo University, 5-28-20 Hakusan, Bunkyo-ku, Tokyo 112-8606, Japan.

Received: 31 March 2020 Accepted: 12 March 2021

Published online: 08 April 2021

\section{References}

Abel GJ, Brottrager M, Cuaresmac JC, Muttarak R (2019) Climate, conflict and forced migration. Glob Environ Chang 54:239-249

Adams C, Ide T, Barnett J, Detges A (2018) Sampling bias in climate-conflict research. Nat Clim Chang 8:200. https://doi.org/10.1038/s41558-018-0068-2

Aerts JCJH, Botzen WJ (2011) Climate change impacts on long-term flood risk and insurance: a comprehensive study for the Netherlands. Glob Environ Chang 21:1045-1060. https://doi.org/10.1016/j.gloenvcha.2011.04.005 
Anderson GB, Bell ML, Peng RD (2013) Methods to calculate the heat index as an exposure metric in environmental health research. Environ Health Perspect 121:1111-1119

Anthoff D, Nicholls RJ, Tol RSJ (2010) The economic impact of substantial sealevel rise. Mitig Adapt Strateg Glob Change 15:321-335. https://doi.org/10.1 007/s11027-010-9220-7

Arnell NW, Brown S, Gosling SN, Gottschalk P, Hinkel J, Huntingford C, LloydHughes B, Lowe JA, Nicholls RJ, Osborn TJ, Osborne TM, Rose GA, Smith P, Wheeler TR, Zelazowski P (2016a) The impacts of climate change across the globe: a multi-sectoral assessment. Clim Chang 134:457-474 https://doi.org/1 0.1007/s10584-014-1281-2

Arnell NW, Brown S, Gosling SN, Hinkel J, Huntingford C, Lloyd-Hughes B, Lowe JA, Osborn T, Nicholls RJ, Zelazowski P (2016b) Global-scale climate impact functions: the relationship between climate forcing and impact. Clim Change 134:475-487 https://doi.org/10.1007/s10584-013-1034-7

Arnell NW, Gosling SN (2016) The impacts of climate change on river flood risk at the global scale. Clim Chang 134:387-401. https://doi.org/10.1007/s10584 014-1084-5

Arnell NW, Lloyd-Hughes B (2014) The global-scale impacts of climate change on water resources and flooding under new climate and socio-economic scenarios. Clim Chang 122:127-140

Bajželj B, Richards K (2014) The positive feedback loop between the impacts of climate change and agricultural expansion and relocation. Land 3:898-916

Bangash RF, Passuello A, Sanchez-Canales M, Terrado M, Lopez A, Elorza FJ, Ziv G, Acuna V, Schuhmacher M (2013) Ecosystem services in Mediterranean river basin: climate change impact on water provisioning and erosion control. Sci Total Environ 458:246-255

Barnett J and Webber M (2009) Accommodating migration to promote adaptation to climate change. A Policy Brief prepared for the Secretariat of the Swedish Commission on Climate Change and Development and the World Bank Report 2010 Team. Available at http://www.ccdcommission.org/ Filer/documents/Accommodating\%20Migration.pdf. Accessed 28 Oct 2020.

Beckage B, Gross L, Lacasse K, Carr E, Metcalf S, Winter J, Howe P, Fefferman N, Franck T, Zia A, Kinzig A, Hoffman F (2018) Linking models of human behaviour and climate alters projected climate change. Nat Clim Chang 8:79-84

Béguin A, Hales S, Rocklö J, Åström C, Louis VR, Sauerborn R (2011) The opposing effects of climate change and socio-economic development on the global distribution of malaria. Glob Environ Chang 21:1209-1214

Behrens P, van Vliet MTH, Nanninga T, Walsh B, Rodrigues JFD (2017) Climate change and the vulnerability of electricity generation to water stress in the European Union. Nature Energy 2:1-7 https://doi.org/10.1038/nenergy.2017.114

Bernauer T, Böhmelt T, Koubi V (2012) Environmental changes and violent conflict. Environ Res Lett 7:015601. https:/doi.org/10.1088/1748-9326/7/1/015601

Berrittella M, Bigano A, Roson R, Tol RSJ (2006) A general equilibrium analysis of climate change impacts on tourism. Tourism Manage 27:913-924

Berry P, Clarke K, Fleury M, Parker S (2014) Health chapter. In: Canada in a changing climate: sector perspectives on impacts and adaptation. Natural Resources Canada, Government of Canada, Ottawa

Bett B, Kiunga P, Gachohi J, Sindato C, Mbotha D, Robinson T, Lindahl J, Grace D (2017) Effects of climate change on the occurrence and distribution of livestock diseases. Prev Vet Med 137:119-129 https://doi.org/10.1016/j. prevetmed.2016.11.019

Bigano A, Bosello F, Roson R, Tol R (2008) Economy-wide impacts of climate change: a joint analysis for sea level rise and tourism. Mitig Adapt Strat Glob Change 13:765-791

Birkmann J, von Teichman K (2010) Integrating disaster risk reduction and climate change adaptation: key challenges_-scales, knowledge, and norms. Sustain Sci 5:171-184

Blanco M, Ramos F, van Doorslaer B, Martínez P, Fumagalli D, Ceglar A, Fernández FJ (2017) Climate change impacts on EU agriculture: a regionalized perspective taking into account market-driven adjustments. Agric Syst 156:52-66 https://doi.org/10.1016/j.agsy.2017.05.013

Bond-Lamberty B, Calvin K, Jones AD, Mao J, Patel P, Shi XY, Thomson A, Thornton P, Zhou Y (2014) On linking an Earth system model to the equilibrium carbon representation of an economically optimizing land use model. Geosci Model Dev 7:2545-2555

Boone RB, Conant RT, Sircely J, Thornton PK, Herrero M (2018) Climate change impacts on selected global rangeland ecosystem services. Glob Change Biol 24:1382-1393

Bosello F, Roson R, Tol RSJ (2006) Economy-wide estimates of the implications of climate change: human health. Ecol Econ 58:579-591
Bosello F, Roson R, Tol RSJ (2007) Economy-wide estimates of the implications of climate change: sea level rise. Environ Resour Econ 37:549-571

Bosworth RC, Hunter A, Kibria A (2017) The value of a statistical life: economics and politics, https://strata.org/pdf/2017/vsl-full-report.pdf

Bouwer LM (2011) Have disaster losses increased due to anthropogenic climate change? B Am Meteorol Soc 92:39-46

Bouwer LM (2013) Projections of future extreme weather losses under changes in climate and exposure. Risk Analysis 33:915-930

Brovkin V, Boysen L, Arora VK, Boisier JP, Cadule P, Chini L, Claussen M, Friedlingstein P, Gayler V, van den Hurk BJJM, Hurtt GC, Jones CD, Kato E, de Noblet-Ducoudré N, Pacifico F, Pongratz J, Weiss M (2013) Effect of anthropogenic land-use and land cover changes on climate and land carbon storage in CMIP5 projections for the 21st century. J Clim 26:6859-6881. https://doi.org/10.1175/JCLI-D-12-00623.1

Burke M, Hsiang SM, Miguel E (2015) Global non-linear effect of temperature on economic production. Nature 527:235-239 https://doi.org/10.1038/nature1 5725

Caldeira K, Brown PT (2019) Reduced emissions through climate damage to the econ-omy. Proc Natl Acad Sci USA 116:714-716 https://doi.org/10.1073/pna s. 1819605116

Calvin K, Bond-Lamberty B (2018) Integrated human-earth system modeling-state of the science and future directions. Environ Res Lett 13:063006

Calvin KV, Bond-Lamberty B, Jones AD, Shi X, Di Vittorio A, Thornton PE (2019) Characteristics of human-climate feedbacks differ at different radiative forcing levels. Global Planet Change 180:126-135. PNN. https://doi.org/10.101 6/j.gloplacha.2019.06.003

Cannon C, Gotham KF, Lauve-Moon K, Powers B (2020) The climate change double whammy: flood damage and the determinants of flood insurance coverage, the case of post-Katrina New Orleans. Climate Risk Manage 27: 100210

Carleton TA, Hsiang SM (2016) Social and economic impacts of climate. Science 353:aad9837. https://doi.org/10.1126/science.aad9837

Chen C-C, McCarl B, Chang C-C (2011) Climate change, sea level rise and rice: global market implications. Clim Chang 110:543-560

Chen Y, Tao Y, Cheng Y, Ju W, Ye J, Hickler T, Liao C, Feng L, Ruan H (2018) Great uncertainties in modeling grazing impact on carbon sequestration: a multimodel inter-comparison in temperate Eurasian Steppe. Environ Res Lett 13: 75005. https://doi.org/10.1088/1748-9326/aacc75

Chilkoti V, Bolisetti T, Balachandar R (2017) Climate change impact assessment on hydropower generation using multi-model climate ensemble. Renew Energ 109:510-517 https://doi.org/10.1016/j.renene.2017.02.041

Chou J, Hu C, Dong W, Ban J (2018) Temporal and spatial matching in humanEarth system model coupling. Earth Space Sci 5:231-239 https://doi.org/10.1 002/2018EA000371

Cloutier C, Locat J, Geertsema M, Jakob M, Schnorbus M (2016) Potential impacts of climate change on landslide occurrence in Canada. In: Ho KKS, Lacasse S, Picarelli $L$ (eds) Slope safety preparedness for impact of climate change. CRC, Boca Raton, pp 71-104

Coffel ED, Horton RM, De Sherbinin A (2017) Temperature and humidity based projections of a rapid rise in global heat stress exposure during the 21 st century. Environ Res Lett 13:014001 https://doi.org/10.1088/17489326/aaa00e

Cole D (2008) The "Stern Review" and its critics: implications for the theory and practice of benefit-cost analysis. Nat Resour J 48:53-90

Collins WD, Craig AP, Truesdale JE, Di Vittorio AV, Jones AD, Bond-Lamberty B, Calvin KV, Edmonds JA, Kim SH, Thomson AM, Patel P, Zhou Y, Mao J, Shi X, Thornton PE, Chini LP, Hurtt GC (2015) The integrated Earth system model version 1: formulation and functionality. Geosci Model Dev 8:2203-2219 https://doi.org/10.5194/gmd-8-2203-2015

Costello A (2009) Managing the health effects of climate change. Lancet 373 : $1693-1733$

Dafermos Y, Nikolaidi M, Galanis G (2018) Climate change, financial stability and monetary policy. Ecol Econ 152:219-234

Davide M, De Cian E, Bernigaud A (2018) Energy for adaptation: connecting the Paris Agreement with the Sustainable Development Goals. SSRN Electron J 2018:25 https://doi.org/10.2139/ssrn.3290449

Davis LW, Gertler PJ (2015) Contribution of air conditioning adoption to future energy use under global warming. Proc Natl Acad Sci USA 112:5962-5967 https://doi.org/10.1073/pnas.1423558112 
Day E, Fankhauser S, Kingsmill N, Costa H, Mavrogianni A (2019) Upholding labour productivity under climate change: an assessment of adaptation options. Clim Policy 19:367-385

de Cian E, Lanzi E, Roson R (2013) Seasonal temperature variations and energy demand: a panel cointegration analysis for climate change impact assessment. Clim Chang 116:805-825 https://doi.org/10.1007/s10584-0120514-5

Debortoli NS, Clark DG, Ford JD, Sayles JS, Diaconescu EP (2019) An integrative climate change vulnerability index for Arctic aviation and marine transportation. Nat Comm 10:2596 https://doi.org/10.1038/s41467-019-10347-1

Di Vittorio AV, Chini LP, Bond-Lamberty B, Mao J, Shi X, Truesdale J, Craig A Calvin K, Jones A, Collins WD, Edmonds J, Hurtt GC, Thornton P, Thomson A (2014) From land use to land cover: restoring the afforestation signal in a coupled integrated assessment-earth system model and the implications for CMIP5 RCP simulations. Biogeosciences 11:6435-6450. https://doi.org/10.51 94/bg-11-6435-2014

Di Vittorio AV, Kyle P, Collins WD (2016) What are the effects of Agro-Ecological Zones and land use region boundaries on land resource projection using the Global Change Assessment Model? Environ Modell Softw 85:246-265

Dietz S, Bowen A, Dixon C, Gradwell P (2016) Climate value at risk' of global financial assets. Nat Clim Chang 6:676-679. https://doi.org/10.1038/nclimate2972

Diffenbaugh NS, Burke M (2019) Global warming has increased global economic inequality. Proc Natl Acad Sci USA 116:9808-9813

Donadelli M, Jüppner M, Riedel M, Schlag C (2017) Temperature shocks and welfare costs. J Econ Dyn Control 82:331-355

Du Q, Kim AM, Zheng Y (2017) Modeling multimodal freight transportation scenarios in Northern Canada under climate change impacts. Res Transportation Bus Manage 23:86-96 https://doi.org/10.1016/j.rtbm.2017.02.002

Dubois G, Ceron JP, Gössling S, Hall CM (2016) Weather preferences of French tourists: lessons for climate change impact assessment. Clim Chang 136:339_ 351 https://doi.org/10.1007/s10584-016-1620-6

Dunne JP, Stouffer RJ, John JG (2013) Reductions in labour capacity from heat stress under climate warming. Nat Clim Chang 3:563-566 http://www.nature. com/articles/nclimate1827

Ebi KL, Ogden NH, Semenza JC, Woodward A (2017) Detecting and attributing health burdens to climate change. Environ Health Perspect 125:085004

Eriksen S, Lind J (2009) Adaptation as a political process: adjusting to drought and conflict in Kenya's drylands. Environmen Manage 43:817-835

Forsius M, Anttila S, Arvola L, Bergstrom I, Hakola H, Heikkinen HI, Jelenius J, Hyvarinen M, Jylha K, Karjalainen J, Kaskinen T, Laine K, Nikinmaa E, LetonenSainio P, Rankinen K, Reinikainen M, Setala H, Vuorenmaa J (2013) Impacts and adaptation options of climate change on ecosystem services in Finland: a model based study. Curr Opin Environ Sustain 5:26-40

Forzieri G, Bianchi A, Silva FBE, Marin Herrera MA, Leblois A, Lavalle C, Aerts JC, Feyen $L$ (2018) Escalating impacts of climate extremes on critical infrastructures in Europe. Glob Environ Chang 48:97-107 https://doi.org/10.1 016/j.gloenvcha.2017.11.007

Friedlingstein P, Cox P, Betts R, Bopp L, von Bloh W, Brovkin V, Cadule P, Doney S, Eby M, Fung I, Bala G, John J, Jones C, Joos F, Kato T, Kawamiya M, Knorr W, Lindsay K, Matthews HD, Raddatz T, Rayner P, Reick C, Roeckner E, Schnitzler K-G, Schnur R, Strassmann K, Weaver K, Yoshikawa C, Zeng N (2006) Climate-carbon cycle feedback analysis: results from the C4MIP model intercomparison. J Clim 19:3337-3353

Fujimori S, lizumi T, Hasegawa T, Takakura J, Takahashi K, Hijioka Y (2018) Macroeconomic impacts of climate change driven by changes in crop yields. Sustainability 10:3673 https://doi.org/10.3390/su10103673

Gariano SL, Guzzetti F (2016) Landslides in a changing climate. Earth Sci Rev 162: 227-252. https://doi.org/10.1016/j.earscirev.2016.08.011

Garrote L (2017) Managing water resources to adapt to climate change: facing uncertainty and scarcity in a changing context. Water Resour Manag 31: 2951-2963

Gosling SN, Arnell NW (2016) A global assessment of the impact of climate change on water scarcity. Clim Chang 134:371-385. https://doi.org/10.1007/ s10584-013-0853-x

Gray CL (2011) Soil quality and human migration in Kenya and Uganda. Glob Environ Change 21:421-430. https://doi.org/10.1016/j.gloenvcha.2011.02.004

Gray CL, Mueller V (2012) Drought and population mobility in rural Ethiopia. World Dev 40:134-145

Gray JS, Dautel H, Estrada-Peña A, Kahl O, Lindgren E (2009) Effects of climate change on ticks and tick-borne diseases in Europe. Interdiscip Perspec Infect Dis:593232 https://doi.org/10.1155/2009/593232
Gregory JM, Jones CD, Cadule P, Friedlingstein P (2009) Quantifying carbon cycle feedbacks. J Clim 22:5232-5250

Grimm NB, Chapin FS III, Bierwagen B, Gonzalez P, Groffman PM, Luo Y, Melton F, Nadelhoffer K, Pairis A, Raymond PA, Schimel J, Williamson CE (2013) The impacts of climate change on ecosystem structure and function. Front Ecol Environ 11:474-482

Gudipudi PP, Underwood BS, Zalghout A (2017) Impact of climate change on pavement structural performance in the United States. Transport Res Part DTr E 57:172-184 https://doi.org/10.1016/j.trd.2017.09.022

Guha I, Roy C (2016) Climate change, migration and food security: evidence from Indian Sundarbans. Int J Theor Appl Sci 8:45-49

Haddeland I, Heinke J, Biemans H, Eisner S, Flörke M, Hanasaki N, Konzmannb M, Ludwigd F, Masakif Y, Scheweb J, Stackeg T, Tesslerh ZD, Wada Y, Wisser D (2014) Global water resources affected by human interventions and climate change. Proc Natl Acad Sci USA 111:3251-3256

Hajima T, Kawamiya M, Watanabe M, Kato E, Tachiiri K, Sugiyama M, Watanabe S, Okajima H, Ito A (2012) Modeling in Earth system science up to and beyond IPCC AR5. Prog Earth Planet Sc 1:1-25. https://doi.org/10.1186/s40645-014-0029-y

Hallegatte S, Ranger N, Mestre O, Dumas P, Corfee Morlot J, Herweijer C, Muir Wood R (2011) Assessing climate change impacts, sea-level rise and storm surge risk in port cities: a case study on Copenhagen. Clim Chang 104:113137. https://doi.org/10.1007/s10584-010-9978-3

Hamilton JM, Maddison DJ, Tol RSJ (2005) Climate change and international tourism: a simulation study. Glob Environ Chang 15:253-266 https://doi.org/1 0.1016/j.gloenvcha.2004.12.009

Hanasaki N, Fujimori S, Yamamoto T, Yoshikawa S, Masaki Y, Hijioka Y, Kainuma M, Kanamori Y, Masui T, Takahashi K, Kanae S (2013) A global water scarcity assessment under Shared Socio-economic Pathways-Part 2: Water availability and scarcity. Hydrol Earth Syst Sci 17:2393-2413

Harper AB, Powell T, Cox PM, House J, Huntingford C, Lenton TM, Sitch S, Burke E, Chadburn SE, Collins WJ, Comyn-Platt E, Daioglou V, Doelman JC, Hayman G, Robertson E, van Vuuren D, Wiltshire A, Webber CP, Bastos A, Boysen L, Ciais P, Devaraju N, Jain AK, Krause A, Poulter B, Shu S (2018) Land-use emissions play a critical role in land-based mitigation for Paris climate targets. Nat Commun 9:2938

Hasegawa T, Fujimori S, Ito A, Takahashi K, Masui T (2017) Global land-use allocation model linked to an integrated assessment model. Sci Total Environ 580:787-796

Hasegawa T, Fujimori S, Takahashi K, Yokohata T, Masui T (2016a) Economic implications of climate change impacts on human health through undernourishment. Clim Change 136:189-202 https://doi.org/10.1007/s1 0584-016-1606-4

Hasegawa T, Park C, Fujimori S, Takahashi K, Hijioka Y, Masui T (2016b) Quantifying the economic impact of changes in energy demand for space heating and cooling systems under varying climatic scenarios. Palgr Comm 2:1-8 https://doi.org/10.1057/palcomms.2016.13

Hauer ME, Fussell E, Mueller V, Burkett M, Call M, Abel K, McLeman R, Wrathall D (2020) Sea-level rise and human migration. Nat Rev Earth Environ 1:28-39 https://doi.org/10.1038/s43017-019-0002-9

Hejazi MI, Edmonds J, Clarke L, Kyle P, Davies E, Chaturvedi V, Wise M, Patel P, Eom J, Calvin K (2014) Integrated assessment of global water scarcity over the 21 st century under multiple climate change mitigation policies. Hydrol Earth Syst Sci 18:2859-2883

Hejazi MI, Voisin N, Liu L, Bramer LM, Fortin DC, Hathaway JE, Huang M, Kyle P, Leung LR, Li HY, Liu Y, Patel PL, Pulsipher TC, Rice JS, Tesfa TK, Vernon CR, Zhou Y (2015) 21st century United States emissions mitigation could increase water stress more than the climate change it is mitigating. Proc Natl Acad Sci USA 112:10635-10640

Hendrix CS (2017) The streetlight effect in climate change research on Africa. Glob Environ Chang 43:137-147

Henry S, Schoumaker B, Beauchemin C (2004) The impact of rainfall on the first out-migration: a multi-level event-history analysis in Burkina Faso. Popul Enviro 25:423-460

Herrero M, Addison J, Bedelian C, Carabine E, Havlik P, Henderson B, Van De Steeg J, Thornton PK (2016a) Climate change and pastoralism: impacts, consequences and adaptation. OIE Rev Sci Tech 35:417-433

Herrero M, Henderson B, Havlik P, Thornton PK, Conant RT, Smith P, Wirsenius S, Hristov AN, Gerber P, Gill M, Butterbach-Bahl K, Valin H, Garnett T, Stehfest E (2016b) Greenhouse gas mitigation potentials in the livestock sector. Nat Clim Chang 6:452-461 https://doi.org/10.1038/nclimate2925 
Herweijer C, Ranger N, Ward RET (2009) Adaptation to climate change: threats and opportunities for the insurance industry. The Geneva Papers 34:360-380

Hewer MJ, Gough WA (2018) Thirty years of assessing the impacts of climate change on outdoor recreation and tourism in Canada. Tourism Manage Perspect 26:179-192 https://doi.org/10.1016/j.tmp.2017.07.003

Honda Y, Kondo M, McGregor G, Kim H, Guo Y-L, Hijioka Y, Yoshikawa M, Oka K, Takano S, Hales S, Kovats RS (2014) Heat-related mortality risk model for climate change impact projection. Environ Health Prev Med 19:56-63

Hsiang S, Kopp R, Jina A, Rising J, Delgado M, Mohan S, Rasmussen DJ, MuirWood R, Wilson P, Oppenheimer M, Larsen K, Houser T (2017) Estimating economic damage from climate change in the United States. Science 356: 1362-1369 https://doi.org/10.1126/science.aal4369

Hsiang SM (2010) Temperatures and cyclones strongly associated with economic production in the Caribbean and Central America. Proc Natl Acad Sci USA 107:15367-15372

Hsiang SM, Burke M, Miguel E (2013) Quantifying the influence of climate on human conflict. Science 341:1235367. https://doi.org/10.1126/science.1235367

Hunter SJ, Haywood AM, Dolan AM, Tindal JC (2019) The HadCM3 contribution to PlioMIP phase 2. Clim Past 15:1691-1713

Huq N, Bruns A, Ribbe L, Huq S (2017) Mainstreaming ecosystem services based climate change adaptation (EbA) in Bangladesh: status, challenges and opportunities. Sustainability 9:926 https://doi.org/10.3390/su9060926

lizumi T, Furuya J, Shen Z, Kim W, Okada M, Fujimori S, Hasegawa T, Nishimori M (2017) Responses of crop yield growth to global temperature and socioeconomic changes. Sci Rep-UK 7:7800 https:/doi.org/10.1038/s41598-017-08214-4

lizumi T, Shiogama H, Imada Y, Hanasaki N, Takikawa H, Nishimori M (2018) Crop production losses associated with anthropogenic climate change for 19812010 compared with preindustrial levels. Int J Climatol 38:5405-5417. https:// doi.org/10.1002/joc.5818

IPCC (2014) Summary for policymakers. In: Field CB, Barros VR, Dokken DJ, Mach KJ, Mastrandrea MD, Bilir TE, Chatterjee M, Ebi KL, Estrada YO, Genova RC, Girma B, Kissel ES, Levy AN, MacCracken S, Mastrandrea PR, White LL (eds) Climate Change 2014: impacts, adaptation, and vulnerability. Part A: Global and sectoral aspects. Contribution of Working Group II to the Fifth Assessment Report of the Intergovernmental Panel on Climate Change. Cambridge University Press, Cambridge and New York

Isaac M, van Vuuren DP (2009) Modeling global residential sector energy demand for heating and air conditioning in the context of climate change. Energ Policy 37:507-521 https://doi.org/10.1016/j.enpol.2008.09.051

Jones AD, Calvin KV, Shi X, Di Vittorio AV, Bond-Lamberty B, Thornton PE, Collins WD (2018) Quantifying human-mediated carbon cycle feedbacks. Geophys Res Lett 45:11,370-11,379 https://doi.org/10.1029/2018GL079350

Kawamiya M, Hajima T, Tachiiri K, Yokohata T (2020) Two decades of Earth system modeling. Prog Earth Planet Sc 7:64

Kaya Y, Yokobori K (eds) (1997) Environment, energy, and economy: strategies for sustainability. United Nations University Press, Tokyo

Kellie-Smith O, Cox PM (2011) Emergent dynamics of the climate-economy system in the Anthropocene. Phil Trans R Soc A 369:868-886. https://doi. org/10.1098/rsta.2010.0305

Kjellstrom T, Briggs D, Freyberg C, Lemke B, Otto M, Hyatt O (2016) Heat, human performance, and occupational health: a key issue for the assessment of global climate change impacts. Annu Rev Public Health 37:97-112

Kjellstrom T, Holmer I, Lemke B (2009a) Workplace heat stress, health and productivity-an increasing challenge for low and middle-income countries during climate change. Glob Health Action 2:2047

Kjellstrom T, Kovats RS, Lloyd SJ, Holt T, Tol RSJ (2009b) The direct impact of climate change on regional labor productivity. Arch Environ Occup Health 64:217-227 http://www.tandfonline.com/doi/abs/10.1080/19338240903352776

Knutson TR, McBride JL, Chan J, Emanuel K, Holland G, Landsea C, Held I, Kossin JP, Srivastava AK, Sugi M (2010) Tropical cyclones and climate change. Nat Geosci 3:157-163

Koetse MJ, Rietveld P (2009) The impact of climate change and weather on transport: an overview of empirical findings. Transp Res Part D 14:205-221

Kreamer DK (2012) The past, present, and future of water conflict and international security. J Contemp Water Res Educ 149:87-95

Krishnamurthy M, Ramalingam P, Perumal K, Kamalakannan LP, Chinnadurai J, Shanmugam R, Srinivasan K, Venugopal V (2017) Occupational heat stress impacts on health and productivity in a steel industry in Southern India. Saf Health Work 8:99-104 https://doi.org/10.1016/j.shaw.2016.08.005

Lafferty KD (2009) The ecology of climate change and infectious diseases. Ecology 90:888-900
Lamperti F, Bosetti V, Roventini A, Tavoni M (2019) The public costs of climateinduced financial instability. Nat Clim Chang 9:829-833

Lawrence DM, Hurtt GC, Arneth A, Brovkin V, Calvin KV, Jones AD, Jones CD, Lawrence PJ, de Noblet-Ducoudré N, Pongratz J, Seneviratne SI, Shevliakova E (2016) The Land Use Model Intercomparison Project (LUMIP) contribution to CMIP6: rationale and experimental design. Geosci Model Dev 9:2973-2998 https://doi.org/10.5194/gmd-9-2973-2016

Lee C, Schlemme C, Murray J, Unsworth R (2015) The cost of climate change: ecosystem services and wildland fires. Ecol Econ 116:261-269

Li X, Chow KH, Zhu Y, Lin Y (2016) Evaluating the impacts of high-temperature outdoor working environments on construction labor productivity in China: a case study of rebar workers. Build Environ 95:42-52 https://doi.org/10.1016/ j.buildenv.2015.09.005

Linnerooth-Bayer J, Mechler R (2006) Insurance for assisting adaptation to climate change in developing countries: a proposed strategy. Clim Policy 6:621-636

López-Carr D (2012) Agro-ecological drivers of rural out-migration to the Maya Biosphere Reserve, Guatemala. Environ Res Lett 7:045603. https://doi.org/10.1 088/1748-9326/7/4/045603

Lopez-i-Gelats F (2014) Impacts of climate change on food availability: livestock In: Freedman B (ed) Global environmental change. Handbook of global environmental pollution, vol 1. Springer, Dordrecht https://doi.org/10.1007/ 978-94-007-5784-4_118

Luyssaert S, Jammet M, Stoy PC, Estel S, Pongratz J, Ceschia E, Churkina G, Don A Erb K, Ferlicoq M, Gielen B, Grünwald T, Houghton RA, Klumpp K, Knohl A, Kolb T, Kuemmerle T, Laurila T, Lohila A, Loustau D, McGrath MJ, Meyfroidt P, Moors EJ, Naudts K, Novick K, Otto J, Pilegaard K, Pio CA, Rambal S, Rebmann C, Ryder J, Suyker AE, Varlagin A, Wattenbach M, Dolman AJ (2014) Land management and land-cover change have impacts of similar magnitude on surface temperature. Nat Clim Chang 4:389-393

Mach KJ, Kraan CM, Adger WN, Buhaug H, Burke M, Fearon JD, Field CB, Hendrix CS, Maystadt J-F, O'Loughlin J, Roessler P, Scheffran J, Schultz KA, von Uexkull N (2019) Climate as a risk factor for armed conflict. Nature 571:193-197. https://doi.org/10.1038/s41586-019-1300-6

Maikhuri RK, Phondani PC, Dhyani D, Rawat LS, Jha NK, Kandari LS (2017) Assessment of climate change impacts and its implications on medicinal plantsbased traditional healthcare system in Central Himalaya, India. Iran I Sci Technol Trans A Sci 42:1827-1835 https://doi.org/10.1007/s40995-017-0354-2

Martin R, Müller B, Linstädter A, Frank K (2014) How much climate change can pastoral livelihoods tolerate? Modelling rangeland use and evaluating risk. Glob Environ Chang 24:183-192

Matsumoto K (2011a) Analyzing economic impacts of CO2 abatement and R\&D promotion in Japan applying a dynamic CGE model with endogenous technological change. J Glob Environ Eng 16:25-33

Matsumoto K (2011b) Economic analysis of CO2 emission abatement applying a dynamic CGE model with endogenous technological change: impacts of the time horizon. J Environ Sci Eng 5:1454-1463

Matsumoto K (2012) Economic implications of CO2 emission reduction in Japan applying a dynamic CGE model with endogenous technological change: use of emission permit revenue. J Environ Sci Eng B 1:945-956

Matsumoto K (2019) Climate change impacts on socioeconomic activities through labor productivity changes considering interactions between socioeconomic and climate systems. J Clean Prod 216:528-541. https://doi. org/10.1016/j.jclepro.2018.12.127

Matsumoto K, Takagi M (2017) Climate change impact and adaptation on rice production in Japan. Environmental. Science 30:346-356. https://doi.org/1 $0.11353 /$ sesj.30.346

Matthews TKR, Wilby RL, Murphy C (2017) Communicating the deadly consequences of global warming for human heat stress. Proc Natl Acad Sci U S A 114:3861-3866

Maystadt J-F, Ecker O (2014) Extreme weather and civil war: does drought fuel conflict in Somalia through livestock price shocks? Am J Agr Econ 96:11571181

McDermid SS, Mearns LO, Ruane AC (2017) Representing agriculture in Earth System Models: approaches and priorities for development. J Adv Model Earth Syst 9:2230-2265. https://doi.org/10.1002/2016MS000749

McLeman R, Smit B (2006) Migration as an adaptation to climate change. Clim Chang 76:31-53

Meiyappana P, Daltonb M, O'Neill BC, Jai AK (2014) Spatial modeling of agricultural land use change at global scale. Ecol Model 291:152-174

Melvin AM, Larsen P, Boehlert B, Neumann JE, Chinowsky P, Espinet X, Martinich J, Baumann MS, Rennels L, Bothner A, Nicolsky DJ, Marchenko SS (2017) 
Climate change damages to Alaska public infrastructure and the economic of proactive adaptation. P Natl Acad Sci USA 114:122-131. https://doi.org/1 0.1073 /pnas. 1611056113

Mendelsohn R, Emanuel K, Chonabayashi S, Bakkensen L (2012) The impact of climate change on global tropical cyclone damage. Nat Clim Change 2:205-209

Mercer J (2010) Disaster risk reduction or climate change adaptation: are were inventing the wheel? J Int Dev 22:247-264

Mercure J-F, Pollitt H, Edwards NR, Holden PB, Chewpreecha U, Salas P, Lam A, Knobloch F, Vinuales J (2018) Environmental impact assessment for climate change policy with the simulation-based integrated assessment model E3ME-FTT-GENIE. Energy Strateg Rev 20:195-208. https://doi.org/10.1016/j. esr.2018.03.003

Meyssignac B, Becker B, Llovel W, Cazenave A (2012) An assessment of two dimensional past sea level reconstructions over 1950-2009 based on tidegauge data and different input sea level grids. Surv Geophys 33:945-972

Millennium Ecosystem Assessment (2005) Ecosystems and human well-being: general synthesis. https://www.millenniumassessment.org/documents/ document.356.aspx.pdf. (last Access 6 Oct 2020).

Mills E (2005) Insurance in a climate of change. Science 309:1040-1044

Monier E, Paltsev S, Sokolov A, Chen YHH, Gao X, Ejaz Q, Couzo E, Schlosser CA, Dutkiewicz S, Fant C, Scott J, Kicklighter D, Morris J, Jacoby H, Prinn R, Haigh M (2018) Toward a consistent modeling framework to assess multi-sectoral climate impacts. Nat Commun 9:1-8. https://doi.org/10.1038/s41467-018-02 984-9

Monioudi I, Asariotis R, Becker A, Bhat C, Dowding-Gooden D, Esteban M, Feyen L, Mentaschi L, Nikolaou A, Nurse L, Phillips W, Smith D, Satoh M, Trotz UO, Velegrakis AF, Voukouvalas E, Vousdoukas MI, Witkop R (2018) Climate change impacts on critical international transportation assets of Caribbean Small Island Developing States (SIDS): the case of Jamaica and Saint Lucia. Reg Environ Change 18:2211-2225

Moore FC, Diaz DB (2015) Temperature impacts on economic growth warrant stringent mitigation policy. Nat Clim Change 5:127-131. https://doi.org/10.1 038/nclimate2481

Mordecai EA, Caldwell JM, Grossman MK, Lippi CA, Johnson LR, Neira M, Rohr JR, Ryan SJ, Savage V, Shocket MS (2019) Thermal biology of mosquito-borne disease. Ecol Lett 22:1690-1708

Mortimore M (2010) Adapting to drought in the Sahel: lessons for climate change. Wires Clim Chang 1:134-143

Morton JF (2007) The impact of climate change on smallholder and subsistence agriculture. P Natl Acad Sci USA 104:19680-19685. https://doi.org/10.1073/ pnas.0701855104

Mueller V, Gray C, Kosec K (2014) Heat stress increases long-term human migration in rural Pakistan. Nat Clim Change 4:182-185

Nardone A, Ronchi B, Lacetera N, Ranieri MS, Bernabucci U (2010) Effects of climate changes on animal production and sustainability of livestock systems. Livest Sci 130:57-69. https://doi.org/10.1016/J.LIVSCI.2010.02.011

National Institute for Occupational Safety and Health (2016) Occupational exposure to heat and hot environments: revised criteria 2016. DHHS Publ 106:1-159

Nelson GC, Rosegrant MW, Koo J, Robertson R, Sulser T, Zhu T, Ringler C, Msang S, Palazzo A, Batka M, Magalhaes M, Valmonte-Santos R, Ewing M, Lee D (2009) Climate change. Impact on agriculture and costs of adaptation. Int Food Policy Res Inst, Washington, DC

Neumann JE, Emanuel K, Ravela S, Ludwig L, Kirshen P, Bosma K, Martinich J (2014) Joint effects of storm surge and sea-level rise on US Coasts: new economic estimates of impacts, adaptation, and benefits of mitigation policy. Clim Chang 129:337-349

Newsham A, Pulido MT, Ulrichs M, Cruz RM, Ocón XC, Shankland A, Cannon T (2018) Ecosystems-based adaptation: are we being conned? Evidence from Mexico. Glob Environ Chang 49:14-26

Ng AKY, Andrews J, Babb D, Lin Y, Becker A (2018) Implications of climate change for shipping: opening the Arctic seas. Wires Clim Change 9:1-18 https://doi.org/10.1002/wcc.507

Nicholls RJ (2011) Planning for the impacts of sea level rise. Oceanography 24 : 144-157

Nnadi FN, Chikaire J, Echetama JA, Ihenacho RA, Umunnakwe PC, Utazi CO (2013) Agricultural insurance: a strategic tool for climate change adaptation in the agricultural sector. Net J Agric Sci 1:1-9

Nordhaus W (2014) Estimates of the social cost of carbon: concepts and results from the DICE-2013R model and alternative approaches. J Assoc Environ Resour Econ 1:273-312 https://doi.org/10.1086/676035
Nordhaus W, Sztorc P (2013) DICE 2013R: introduction and user's manual. Available via http://www.econ.yale.edu/ nordhaus/homepage/homepage/ documents/DICE_Manual_100413r1.pdf. Accessed 1 Oct 2020.

Nordhaus WD (1994) Managing the global commons: the economics of climate change. The MIT Press, Cambridge

Nordhaus WD, Boyer J (1999) Roll the DICE again: economic models of global warming. Yale University. http://www.econ.yale.edu/ nordhaus/homepage/ homepage/rice98\%20pap\%20121898.PDF

Noy I (2009) The macroeconomic consequences of disasters. J Dev Econ 88:221-231 Nurse LA, RF ML, Agard J, Briguglio LP, Duvat-Magnan V, Pelesikoti N, Tompkins E, Webb A (2014) In: Barros VR, Field CB, Dokken DJ, Mastrandrea MD, Mach KJ, Bilir TE, Chatterjee M, Ebi KL, Estrada YO, Genova RC, Girma B, Kissel ES, Levy AN, MacCracken S, Mastrandrea PR, White LL (eds) Small islands. In: Climate change 2014: impacts, adaptation, and vulnerability. Part B: Regional aspects. Contribution of Working Group II to the Fifth Assessment Report of the Intergovernmental Panel on Climate Change. Cambridge University Press, Cambridge and New York, pp 1613-1654

O'Neill BC, Tebaldi C, van Vuuren DP, Eyring V, Friedlingstein P, Hurtt G, Knutti R, Kriegler E, Lamarque J-F, Lowe J, Meehl GA, Moss R, Riahi K, Sanderson BM (2016) The Scenario Model Intercomparison Project (ScenarioMIP) for CMIP6. Geosci Model Dev 9:3461-3482 https://doi.org/10.5194/gmd-9-3461-2016

Obradovich N, Rahwan I (2019) Risk of a feedback loop between climatic warming and human mobility. J R Soc Interface 16:20190058 https://doi. org/10.1098/rsif.2019.0058

Olwoch JM, Reyers B, Engelbrecht FA, Erasmus BFN (2008) Climate change and the tick-borne disease, Theileriosis (East Coast fever) in sub-Saharan Africa. J Arid Environ 72:108-120 https://doi.org/10.1016/j.jaridenv.2007.04.003

Paterson J, Berr P, Ebi K, Varangu L (2014) Health care facilities resilient to climate change impacts. Int J Environ Res Public Health 11:13097-13116

Pongratz J, Dolman H, Don A, Erb K-H, Fuchs R, Herold M, Jones C, Kuemmerle T, Luyssaert S, Meyfroidt P, Naudts K (2018) Models meet data: challenges and opportunities in implementing land management in Earth system models. Glob Chang Biol 24:1470-1487

Pregnolato M, Ford A, Glenis V, Wilkinson S, Dawson R (2017) Impact of climate change on disruption to Urban transport networks from pluvial flooding. J Infrastruct Syst 23:1-13 https://doi.org/10.1061/(ASCE)IS.1943-555X.0000372

Prestele P, Alexander P, Rounsevell M, Arneth A, Calvin K, Doelman J, Eitelberg D, Engström K, Fujimori S, Hasegawa T, Havlik P, Humpenöder F, Jain A, Krisztin T, Kyle P, Meiyappan P, Popp A, Sands R, Schaldach R, Schüngel J, Stehfest E, Tabeau A, Van Meijl H (2016) Hotspots of uncertainty in land use and land cover change projections: a global scale model comparison. Glob Chang Biol 22:3967-3983

Pryor SC, Barthelmie RJ, Schoof JT (2012) Past and future wind climates over the contiguous USA based on the North American Regional Climate Change Assessment Program model suite. J Geophys Res-Atmos 117:1-17 https://doi. org/10.1029/2012JD017449

Ramankutty N, Foley JA, Norman J, McSweeney K (2002) The global distribution of cultivable lands: current patterns and sensitivity to possible climate change. Glob Ecol Biogeogr 11:377-392

Raymundo R, Asseng S, Robertson R, Petsakos A, Hoogenboom G, Quiroz R, Hareau G, Wolf J (2018) Climate change impact on global potato production. Eur J Agron 100:87-98

Reilly J, Paltsev S, Felzer B, Wang X, Kicklighter D, Melillo J, Prinn R, Sarofim M, Sokolov A, Wang C (2007) Global economic effects of changes in crops, pasture, and forests due to changing climate, carbon dioxide, and ozone. Energ Policy 35:5370-5383

Rezai A, Taylor L, Foley D (2018) Economic growth, income distribution, and climate change. Ecol Econ 146:164-172 https://doi.org/10.1016/j.ecolecon.2017.10.020

Rivera-Ferre MG, Lopez-i-Gelats F, Howden M, Smith P, Morton JF, Herrero M (2016) Re-framing the climate change debate in the livestock sector: mitigation and adaptation options. Wires Clim Change 7:869-892 https://doi. org/10.1002/wCc.421

Robinson DT, Di Vittorio A, Alexander P, Arneth A, Barton CM, Brown DG, Kettner A, Lemmen C, O'Neill BC, Janssen M, Pugh TAM, Rabin SS, Rounsevell M, Syvitski JP, Ullah I, Verburg PH (2018) Modelling feedbacks between human and natural processes in the land system. Earth Syst Dynam 9:895-914

Rogelj J, Forster PM, Kriegler E, Smith C, Séférian R (2019) Estimating and tracking the remaining carbon budget for stringent climate targets. Nature 571:335

Rojas-Downing MM, Nejadhashem AP, Harrigan T, Woznicki SA (2017) Climate change and livestock: impacts, adaptation, and mitigation. Climate Risk Manage 16:145-163 
Rosenzweig C, Elliott J, Deryng D, Ruane AC, Müller C, Arneth A, Boote KJ, Folberth C, Glotter M, Khabarov N, Neumann K, Piontek F, Pugh TAM, Schmid E, Ste-hfest E, Yang H, Jones JW (2014) Assessing agricultural risks of climate change in the 21st century in a global gridded crop model intercomparison. P Natl Acad Sci USA 11:3268-3273. https://doi.org/10.1073/pnas.1222463110 Rosenzweig C, Parry ML (1994) Potential impact of climate change on world food supply. Nature 367:133-138

Roson R, Sartori M (2016) Estimation of climate change damage functions for 140 regions in the GTAP 9 Database. J Glob Econ Anal 1:78-115 https://doi.org/1 0.21642 /jgea.010202sm1f

Roson R, van der Mensbrugghe D (2012) Climate change and economic growth: impacts and interactions. Int J Sustain Econ 4:270-285 https://doi.org/10.1 504/IJSE.2012.047933

Rübbelke D, Vögele S (2011) Impacts of climate change on European critical infrastructures: the case of the power sector. Environ Sci Pol 14:53-63 https:// doi.org/10.1016/j.envsci.2010.10.007

SCBD (2009) Biodiversity and climate-change adaptation. Technical series. In: Connecting biodiversity and climate change mitigation and adaptation: report of the second ad hoc technical expert group on biodiversity and climate change. Secretariat of the Convention on Biological Diversity, Montreal Available via https://www.cbd.int/doc/publications/cbd-ts-41-en. pdf. (Accessed 22 Oct 2020)

Schewe J, Heinke J, Gerten D, Haddeland I, Arnell NW, Clark DB, Dankers R, Eisner S, Fekete BM, Colon-Gonzalez FJ, Gosling SN, Kim H, Liu X, Masaki Y, Portmann FT, Satoh Y, Stacke T, Tang Q, Wada Y, Wisser D, Albrecht T, Frieler K, Piontek F, Warszawski L, Kabat P (2014) Multimodel assessment of water scarcityunder climate change. Proc Natl Acad Sci USA 111:3245-3250. https://doi.org/10.1073/pnas.1222460110

Schilling J, Akuno M, Scheffran J, Weinzierl T (2011) On arms and adaptation: climate change and pastoral conflict in northern Kenya. Climate Change and Security Research Group, University of Hamburg. Available via https://www. clisec.uni-hamburg.de/pdf/working-paper-clisec-15.pdf. Accessed 24 Oct 2020

Schleussner C-F, Donges JF, Donner RV, Schellnhuber HJ (2016) Armed-conflict risks enhanced by climate-related disasters in ethnically fractionized countries. P Natl Acad Sci USA 113:9216-9221

Scott D, Becken S (2010) Adapting to climate change and climate policy: progress, problems and potentials. J Sustain Tour 18:283-295. https://doi. org/10.1080/09669581003668540

Scott D, Hall CM, Stefan G (2012) Government, industry and destination adaptation to climate change. In: Tourism and climate change: impacts, adaptation and mitigation. Routledge, London

Séguin J (2008) Human health in a changing climate: a Canadian assessment of vulnerabilities and adaptive capacity. Health Canada, Ottawa

Shaw MR, Pendleton L, Cameron DR, Morris B, Bachelet D, Klausmeyer K, MacKenzie J, Conklin DR, Bratman GN, Lenihan J, Haunreiter E, Daly C, Roehrdanz PR (2011) The impact of climate change on California's ecosystem services. Clim Change 109:465-484

Shayegh S (2017) Outward migration may alter population dynamics and income inequality. Nat Clim Chang 7:828-832

Smit B, Skinner MW (2002) Adaptation options in agriculture to climate change: a typology. Mitig Adapt Strat Gl 7:85-114

Sokolov AP, Schlosser CA, Dutkiewicz S, Paltsev S, Kicklighter DW, Jacoby HD, Prinn RG, Forest CE, Reilly JM, Wang C, Felzer BS (2005) MIT integrated global system model (IGSM) version 2: model description and baseline evaluation. MIT Joint Program on the Science and Policy of Global Change.

Solomon N, Birhane E, Gordon C, Haile M, Taheri F, Azadi H, Scheffran J (2018) Environmental impacts and causes of conflict in the horn of Africa: a review. Earth Sci Rev 177:284-290

Sovacool B (2018) Bamboo beating bandits: conflict, inequality, and vulnerability in the political ecology of climate change adaptation in Bangladesh. World Dev 102:183-194

Sovacool BJ (2012) Expert views on climate change adaptation in the Maldives. Clim Chang 114:295-300

Sovacool BK (2011) Conceptualizing hard and soft paths for climate change adaptation. Climate Policy 11:1177-1183

Staudinger MD, Grimm NB, Staudt A, Carter SL, Stuart Chapin F III, Kareiva P, Ruckelshaus M, Stein BA (2012) Impacts of climate change on biodiversity, ecosystems, and ecosystem services: technical input to the 2013 National Climate Assessment. Cooperative Report to the 2013 National Climate Assessment.
Steiger R, Scott D, Abegg B, Pons M, Aall C (2019) A critical review of climate change risk for ski tourism. Curr Issues Tour 22(11):1343-1379 https://doi. org/10.1080/13683500.2017.1410110

Stern N (2007) The economics of climate change: The Stern Review. Cambridge University Press, Cambridge

Stojanov R, Duží B, Kelman I, Němec D, Procházka D (2017) Local perceptions of climate change impacts and migration patterns in Malé, Maldives. Geogr J 183:370-385. https://doi.org/10.1111/geoj.12177

Suzuki-Parker A, Kusaka H (2016) Future projections of labor hours based on WBGT for Tokyo and Osaka, Japan, using multi-period ensemble dynamical downscale simulations. Int J Biometeorol 60:307-310 http://link.springer. com/10.1007/s00484-015-1001-2

Tacoli C (2009) Crisis or adaptation? Migration and climate change in a context of high mobility. Environ Urban 21:513-525. https://doi.org/10.1177/095624 7809342182

Takakura J, Fujimori S, Hanasaki N, Hasegawa T, Hirabayashi Y, Honda Y, lizumi T, Kumano N, Park C, Shen Z, Takahashi K, Tamura M, Tanoue M, Tsuchida K, Yokoki H, Zhou Q, Oki T, Hijioka Y (2019) Dependence of economic impacts of climate change on anthropogenically directed pathways. Nat Clim Chang 9:737-741 https://doi.org/10.1038/s41558-019-0578-6

Takakura J, Fujimori S, Takahashi K, Hasegawa T, Honda Y, Hanasaki N, Hijioka Y, Masui T (2018) Limited role of working time shift in offsetting the increasing occupational-health cost of heat exposure. Earth's Futur 6:1588-1602 https:// doi.org/10.1029/2018EF000883

Takakura J, Fujimori S, Takahashi K, Hijioka Y, Hasegawa T, Honda Y, Masui T (2017) Cost of preventing workplace heat-related illness through worker breaks and the benefit of climate-change mitigation. Environ Res Lett 12: 064010 https://doi.org/10.1088/1748-9326/aa72cc

Tamura M, Kumano N, Yotsukuri M, Yokoki H (2019) Global assessment of the effectiveness of adaptation in coastal areas based on RCP/SSP scenarios. Clim Change 152:363-377

Tawatsupa B, Yiengprugsawan V, Kjellstrom T, Berecki-Gisolf J, Seubsman S-A Sleigh A (2013) Association between heat stress and occupational injury among Thai workers: findings of the Thai cohort study. Ind Health 51:34-46 Available via http://jlc.jst.go.jp/DN/JST.JSTAGE/indhealth/2012-0138?lang= en\&from $=$ CrossRef\&type $=$ abstract

Tenggren S, Olsson O, Vulturius G, Carlsen H, Benzie M (2020) Climate risk in a globalized world: empirical findings from supply chains in the Swedish manufacturing sector. J Environ Plan Manag 63:1266-1282 https://doi.org/1 $0.1080 / 09640568.2019 .1660626$

The Economics of Ecosystems and Biodiversity (TEEB) (2009) TEEB Climate Issues Update. Available via http://www.teebweb.org/media/2009/09/TEEB-ClimateIssues-Update.pdf. (Accessed 1 Oct 2020)

Thornton PE, Calvin K, Jones AD, Di Vittorio AV, Bond-Lamberty B, Chini L, Shi X, Mao J, Collins WD, Edmonds J, Thomson A, Truesdale J, Craig A, Branstetter ML, Hurtt G (2017) Biospheric feed-back effects in a synchronously coupled model of human and Earth systems. Nat Clim Chang 7:496-500 https://doi. org/10.1038/nclimate3310

Tol R (2018) The economic impacts of climate change. Rev Env Econ Policy 12:4-25

Tol RSJ (2002a) Estimates of the damage costs of climate change Part 1: Benchmark estimates. Environ Res Econ 21:47-73 https://doi.org/10.1023/A:1014500930521

Tol RSJ (2002b) Estimates of the damage costs of climate change Part II: Dynamic estimates. Environ Res Econ 21:135-160 https:/doi.org/10.1023/A:1014539414591

Trenberth KE (2008) The impact of climate change and variability on heavy precipitation, floods, and droughts. In: Anderson MG (ed) Encyclopedia of Hydrological Sciences. Wiley, Hoboken. https:/doi.org/10.1002/0470848944.hsa211

Ueckerdt F, Frieler K, Lange S, Wenz L, Luderer G, Levermann A (2019) The economically optimal warming limit of the planet. Earth Syst Dynam 10:741763 https://doi.org/10.5194/esd-10-741-2019

Underwood BS, Guido Z, Gudipudi P, Feinberg Y (2017) Increased costs to US pavement infrastructure from future temperature rise. Nat Clim Chang 7:704707 https://doi.org/10.1038/nclimate3390

Underwood EC, Hollandera AD, Safford HD, Kimd JB, Srivastava L, Drapekd RJ (2019) The impacts of climate change on ecosystem services in southern California. Ecosyst Serv 39:101008

van Vliet MTH, Wiberg D, Leduc S, Riahi K (2016) Power-generation system vulnerability and adaptation to changes in climate and water resources. Nat Clim Chang 6:375-380 https://doi.org/10.1038/nclimate2903

van Vliet MTH, Yearsley JR, Ludwig F, Vögele S, Lettenmaier DP, Kabat P (2012) Vulnerability of US and European electricity supply to climate change. Nat Clim Chang 2:676-681 https://doi.org/10.1038/nclimate1546 
van Vuuren DP, Batlle Bayer L, Chuwah C, Ganzeveld L, Hazeleger W, van den Hurk B, van Noije T, O'Neill B, Strengers BJ (2012) A comprehensive view on climate change: coupling of earth system and integrated assessment models. Environ Res Lett 7:024012. https://doi.org/10.1088/1748-9326/7/2/024012

Wada Y, Van Beek LPH, MFP B (2011) Modelling global water stress of the recent past: on the relative importance of trends in water demand and climate variability. Hydrol Earth Syst Sci 15:3785-3805

Waite M, Cohen E, Torbey H, Piccirilli M, Tian Y, Modi V (2017) Global trends in urban electricity demands for cooling and heating. Energy 127:786-802 https://doi.org/10.1016/j.energy.2017.03.095

Warren R, Hope C, Mastrandrea M, Tol R, Adger N, Lorenzoni I (2006) Spotlighting Impacts Functions in Integrated Assessment. Working Paper 91, Tyndall Centre on Climate Change Research.

Watson L, Straatsma MW, Wanders N, Verstegen JA, de Jong SM, Karssenberg D (2020) Global ecosystem service values in climate class transitions. Environ Res Lett 15:024008

Wilson AJ, Mellor PS (2009) Bluetongue in Europe: past, present and future. Philos Trans R Soc B Biol Sci 364:2669-2681 https://doi.org/10.1098/rstb.2009.0091

Woodard DL, Davis SJ, Randerson JT (2019) Economic carbon cycle feedbacks may offset additional warming from natural feedbacks. P Natl Acad Sci U S A 116:759-764

Wu X, Lub Y, Zhou S, Chen L, Xua B (2016) Impact of climate change on human infectious diseases: empirical evidence and human adaptation. Environ Int 86:14-23

Xiang J, Bi P, Pisaniello D, Hansen A (2014) Health impacts of workplace heat exposure: an epidemiological review. Ind Health 52:91-101

Yang S, Dong W, Chou J, Feng J, Wei Z, Guo Y, Wen X, Wei T, Tian D, Zhu X, Yang Z (2016) Global warming projections using the human-earth system model BNU-HESM1.0. Sci Bull 61(23):1833-1838

Yang S, Dong W, Chou J, Feng J, Yan X, Wei Z, Yuan W, Guo Y, Tang Y, Hu J (2015) A brief introduction to BNU-HESM1.0 and its earth surface temperature simulations. Adv Atmos Sci 32(12):1683-1688

Yokohata T, Kinoshita T, Sakurai G, Pokhrel Y, Ito A, Okada M, Satoh Y, Kato E, Nitta T, Fujimori S, Felfelani F, Masaki Y, lizumi T, Nishimori M, Hanasaki N Takahashi K, Yamagata Y, Emori S (2020) MIROC-INTEG-LAND version 1: a global biogeochemical land surface model with human water management, crop growth, and land-use change. Geosci Model Dev 13:4713-4747 https:// doi.org/10.5194/gmd-13-4713-2020

Yokohata T, Tanaka K, Nishina K, Takahashi K, Emori S, Kiguchi M, Iseri Y, Honda Y, Okada M, Masaki Y, Yamamoto A, Shigemitsu M, Yoshimori M, Sueyoshi T, Iwase K, Hanasaki N, Ito A, Sakurai G, lizumi T, Nishimori M, Lim WH, Miyazaki C, Okamoto A, Kanae S, Oki T (2019) Visualizing the interconnections among climate risks. Earth's Future 7:85-100

Zhang P, Deschenes O, Meng K, Zhang J (2018) Temperature effects on productivity and factor reallocation: evidence from a half million Chinese manufacturing plants. J Environ Econ Manage 88:1-17 https://doi.org/10.101 6/j.jeem.2017.11.001

Zhou Q, Hanasaki N, Fujimori S, Masaki Y, Hijioka Y (2018a) Economic consequences of global climate change and mitigation on future hydropower generation. Clim Chang 147:77-90 https://doi.org/10.1007/s1 0584-017-2131-9

Zhou Q, Hanasaki N, Fujimori S, Yoshikawa S, Kanae S, Okadera T (2018b) Cooling water sufficiency in a warming world: projection using an integrated assessment model and a global hydrological model. Water 10:1-14 https:// doi.org/10.3390/w10070872

Zimmermann A, Webber H, Zhao G, Ewert F, Kros J, Wolf J, Britz W, de Vries W (2017) Climate change impacts on crop yields, land use and environment in response to crop sowing dates and thermal time requirements. Agric Syst 157:81-92 https://doi.org/10.1016/j.agsy.2017.07.007

\section{Publisher's Note}

Springer Nature remains neutral with regard to jurisdictional claims in published maps and institutional affiliations.

\section{Submit your manuscript to a SpringerOpen ${ }^{\circ}$ journal and benefit from:}

- Convenient online submission

- Rigorous peer review

- Open access: articles freely available online

- High visibility within the field

- Retaining the copyright to your article

Submit your next manuscript at $\boldsymbol{\nabla}$ springeropen.com 